\title{
الحلقة المفقودة في معادلة الحضارة من منظور التنوير الياباني: إنجازات العزلة وتطورات الانفتاح
}

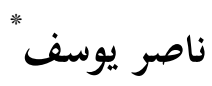

$$
\begin{aligned}
& \text { الملنحص } \\
& \text { يهدف هذا البحث إلى استكناه الأنموذج الإنمائي الياباني داخل العناصر الحضارية التي ارتسمها مالك بن نبي: }
\end{aligned}
$$

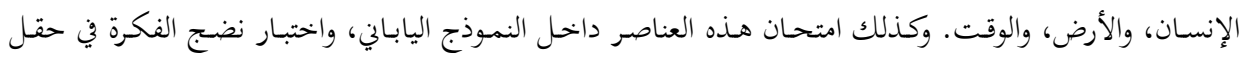

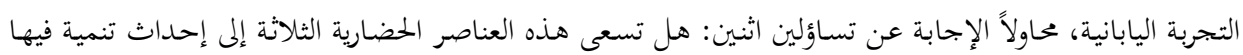

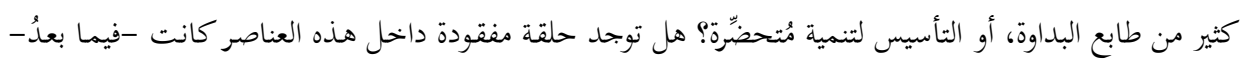

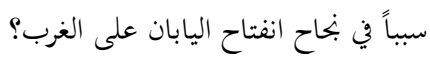

$$
\begin{aligned}
& \text { وقد انتهينا إلى أنّ منظومة العلاقة الدولة-الإنسان هي الحلقة المفقودة في المعادلة الحضارية؛ فمـن غيرها تبقى } \\
& \text { عناصرها كما ارتسمها ابن نبي بدويةً، وعلى نحو ما عاينه ابن خلدون أيضاً. } \\
& \text { الكلمات المفتاحية: اليابان، البداوة، الحضارة، العزلة، الإقطاع، الانفتاح، التنمية. }
\end{aligned}
$$

\section{The Missing Link in the Equation of Civilization from the Perspective of Japanese Enlightenment: Achievements of Isolation and Development of Openness}

\section{Abstract}

The study aspires to investigate the Japanese model of development based on the elements of civilization - namely man, the earth and time - as portrayed by Malik bin Nabi. It intends to examine these civilizational elements in the context of the Japanese model, and to investigate the level of maturity of civilizational thoughts in the Japanese experience. The study tries to answer two questions: first, are those three elements of civilization moving towards development that is characterized more by nomadism or towards civilized development? Second, is there a missing link within those civilizational elements that was later the cause of Japan's successful opening to the West? The study concludes that the state-man relationship is the missing link in the equation of civilization, and without this additional element, development, as portrayed by Ibn Nabi and Ibn Khaldoun, remains nomadic.

Key words: Japan, Nomadism, Civilization, Isolation, Feudalism, Openness, Development

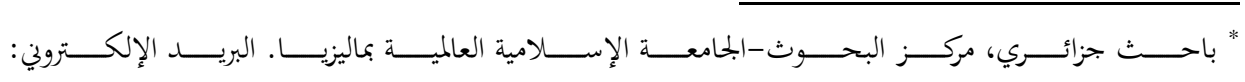

$$
\begin{aligned}
& \text { youcef.nasser@gmail.com }
\end{aligned}
$$

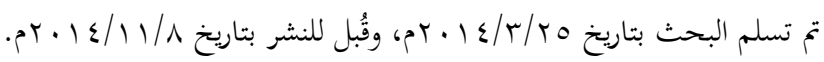




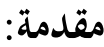

يستعرض البحث عناصر المعادلة الحضارية (الإنسان، الأرض، الوقت) كما تواضع عليها مالك بن نبي، وارتسمها طريقاً حضارياً. وفي الوقت الذي نميل فيه إلى أنّ اليابان

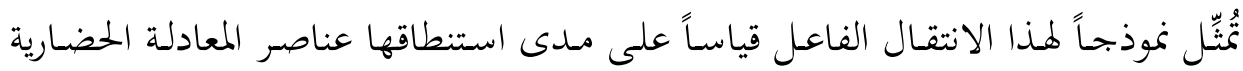
وترجمتها إلى علامات هادية؛ فقد وقفت هي الأخرى على إضافات رسّخت واقع المعادلة الحضارية وأغنته، وبصّرت الرؤية أمام تصوّر مستقبل أفضل وأبلجته.

ونحن إذ نقـف على مسألة التنوير، فإنبّه لا بُدّد مـن الإشـارة إلى الميجي (أي السمُنوّر)

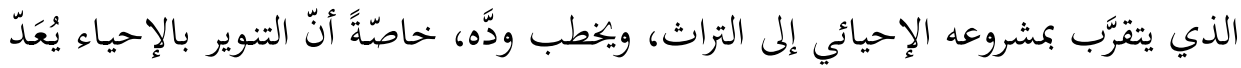

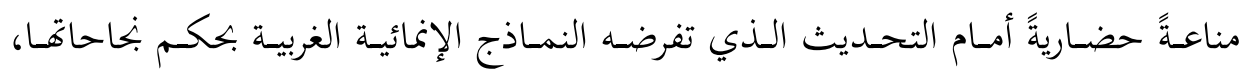
وبسط مقولاتما.

وقـــ ارتأينـا اسـتخدام بعضض المفــاهيم دون غيرهـا، مثـل: البـداوة، والحضـارة؛ لأكّـا وحدات التحليل التي استعملها ابن خلدون، وابن نبي. وبالرغم من وجود كتابات انتصرت لميجي، وعَدَّته مهندس النهضة، إلّا أنّ بحثنا هو

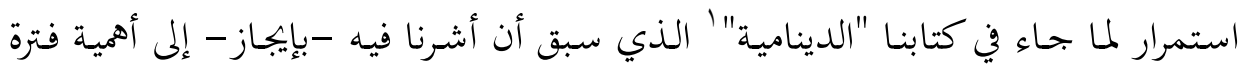
توكوغاوا في إبحاح مهمة ميجي، ونحاول ها هنا معالجحة العزلة اليابانية على نهوِ مُوسَّع. إنّ مـا يدعونا إلى الاهتمـام بالتجربـة اليابانية، هـو أنّ العيش في جماعـة يكاد يكون

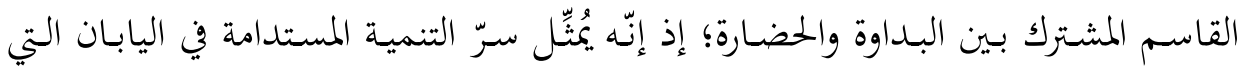

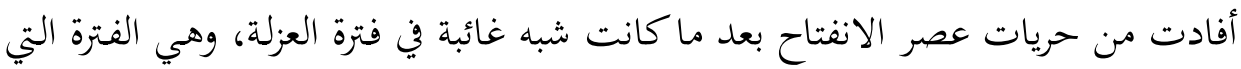

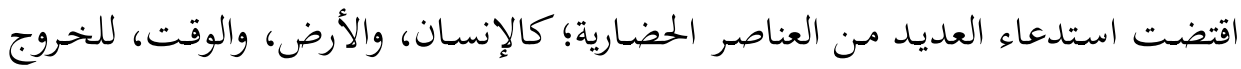

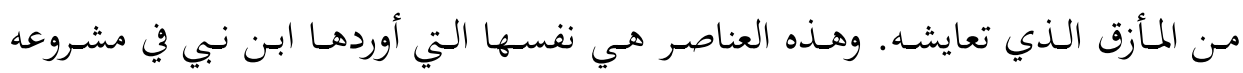

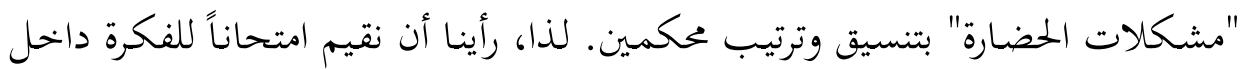

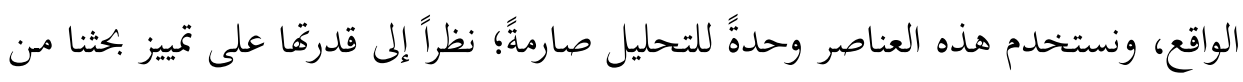
' يوسف، ناصر . ديناميـة التجربـة اليابانيـة في التنمية المركّبة: دراسة مقارنة بـالجزائر وماليزيا، بيروت: مركز

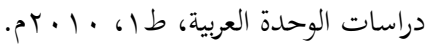


الكتابات السردية التي تنتصر لتوكوغـاوا وتنقل إبحازاته مـ غير فحص ومسـاءلة، وأخحذ العبر؛ جرياً على طريقة ابن خلدون وابن نبي.

إنّ ما سنبرزه يؤكّد حقيقة أنّ عناصر الحضارة تكون فاعلة في إرساء دعائم التحضّر وترسيخها في ظلّ وجود الدولة-التنمية، على شرط استنادها إلى القيم التاريخية الفاعلة، والقيم الحضارية العاملة. وتأسيساً على ذلك، فإنتّا سنتعامل مع عناصر الحضارة، إلى جانب الدولة-التنمية،

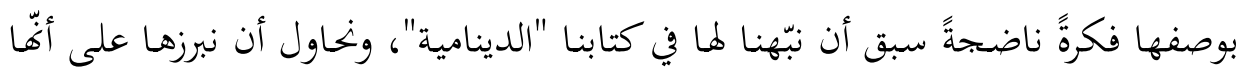

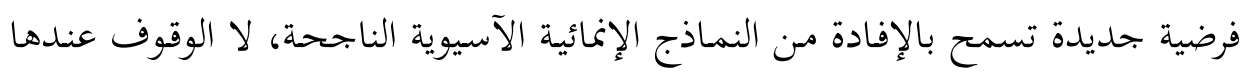

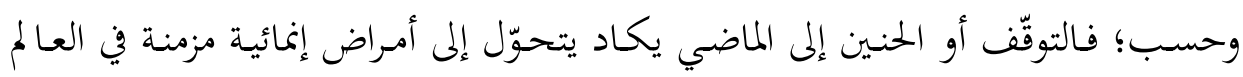
العربي الإسلامي.

ويسعى بحثنا أيضاً إلى تسليط الضوء على فترة الإقطاع التي تمثَّلت عناصر الحضارة

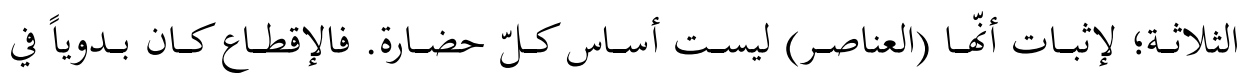
تصرّفاته الإنمائية، ومع ذلك فقد تحقَّقت فيه هـذه العناصر الحضارية بامتياز . أمّا عصر

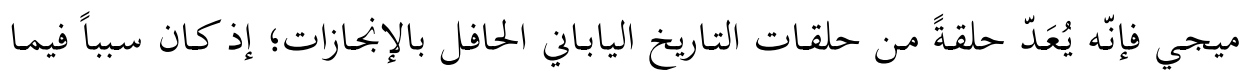

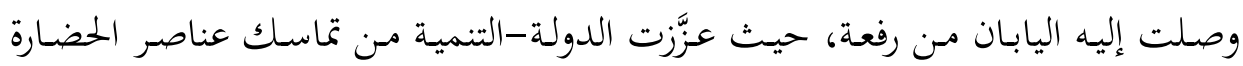
واستدامتها.

وهكذا تنطلق هذه الدراسة في محاورها الرئيسة، بدءاً بإقطاعية توكوغاوا، وانتهاءً بفترة

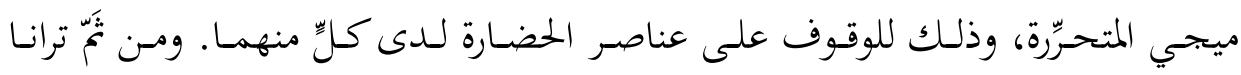

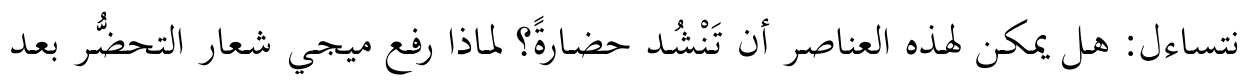
انقطاع الإقطاع؟ ألم تكن هناك علامات تُخبِر عن جنين حضاري يُطِلِ من رحمى توكوغاوا

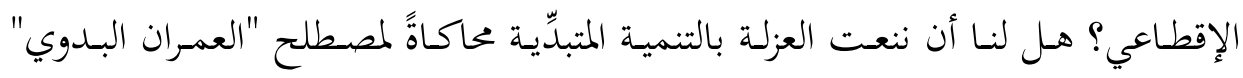
على نحو ما عاينه ابن خلدون؟ ومن الأسئلة التي تعترض سبيلنا أيضاً: 
-هل وقف اليابانيون على المعادلة الحضارية في فترة العزلة؟

-هل استطاع اليابانيون فلكّ العناصر الحضارية وتحويلها إلى علامات هادية للعزلة؟ -هـل كانتت العناصر الحضـارية التي تشَكَّت معالمها في فترة العزلة كافيةً لإححداث تنمية متحضرّة

-هل توجد حلقة مفقودة داخل هذه العناصر كانت سبباً في بناح الانفتاح، وتخطّي مرحلته الحرجة من غير تعجيل الفشل وتحصيله؟

\section{أولاً: فاعلية الإقطاع التوكوغاوي (التنمية المتبدِية)}

لقد أسهم الأوروبيون في القرن التاسع عشر الميلادي في تضخيم العزلة (مباج ام--

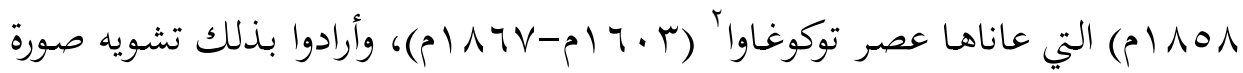
اليابـان، مـع أنّ اليابـان في هـذا العصر (القـرن السـابع عشـر الميلادي تحديداً) كانت قـد

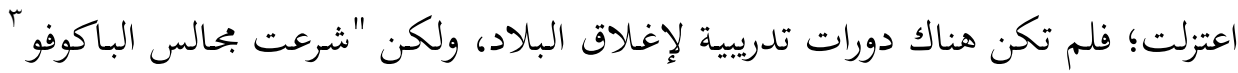
باتخاذ قرارات عدها سياسة واعية تمثلت في إيقاف العلاقات السياسية مع الخارج، وفرض قيود على تصدير الأسلحة، ومنع دخول المسيحية إلى اليابان، وحظر سفر اليابانيين إلى

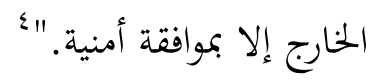

وقـد تونَّت هـذه السياسـة تحصيل الاستقرار، لا الانطواء على الذات؛ إذ جعلت

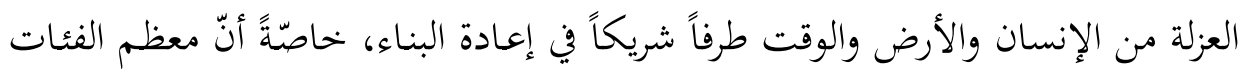

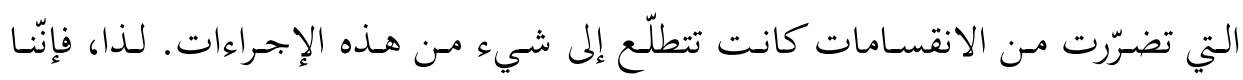

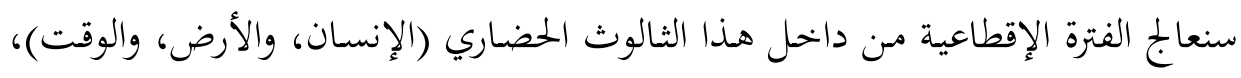

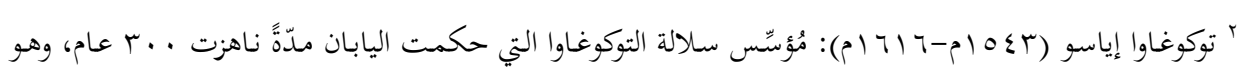

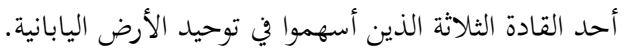

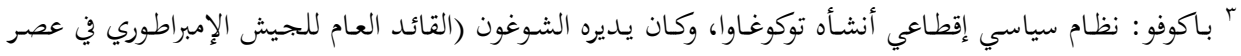
توكوغاوا).

${ }^{4}$ Toby, Ronal P. State and Diplomacy in Early Modern Japan: Asia in the Development of the Tokugawa Bakufu, Stanford: Stanford University Press, 1991, p11-12. 


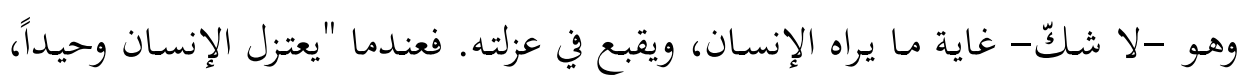

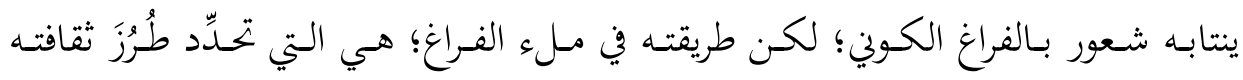

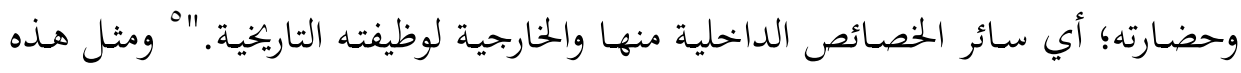
المُحدِّدات هي ما سعت العزلة اليابانية إلى استثمارها.

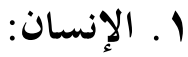

يكمن سرّ تفوّق الإنسان الياباني وتميّزه في بذل الجههد بمعايير عملية بتعل صاحبها

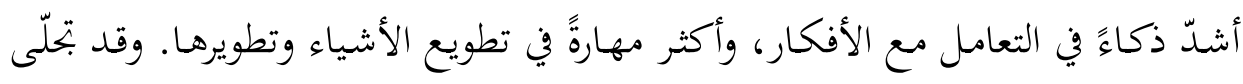

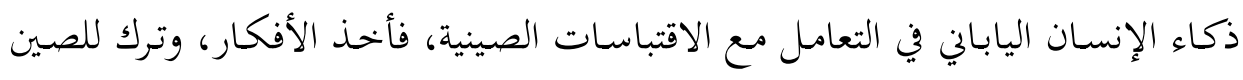

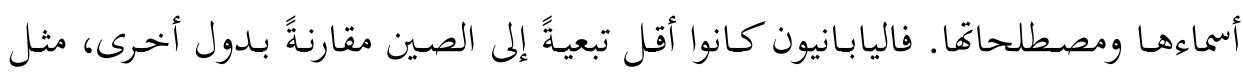

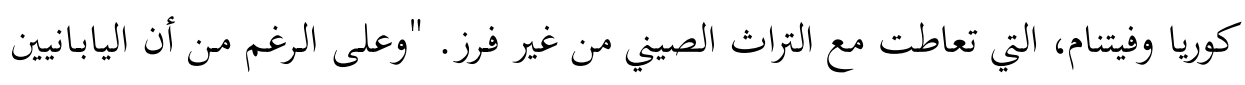

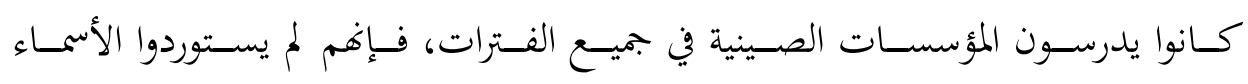

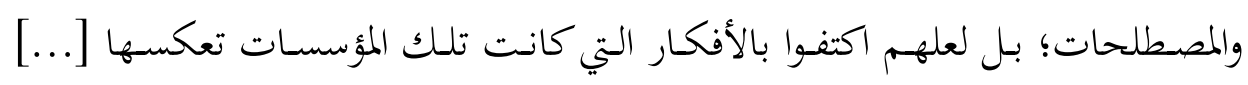

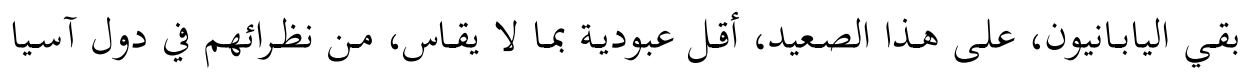
الشرقية." التي اليانيون

وهذا التمييز بين الشكل والمضمون ليس أمراً هَيّناً يُتِقِن فعله كلّ إنسان؛ فإنّّ اليابان

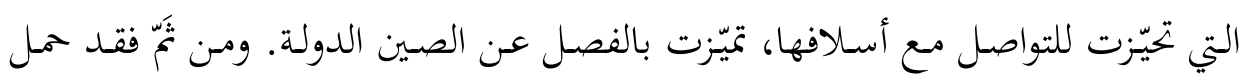

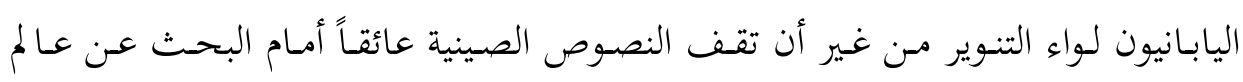

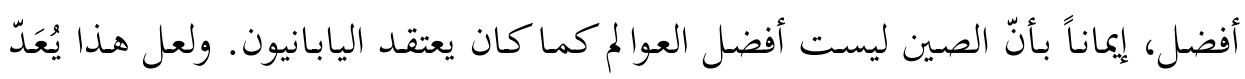

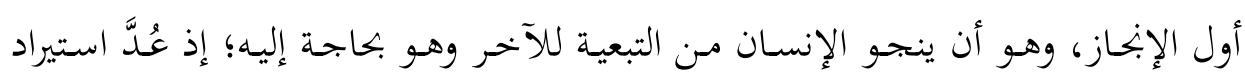

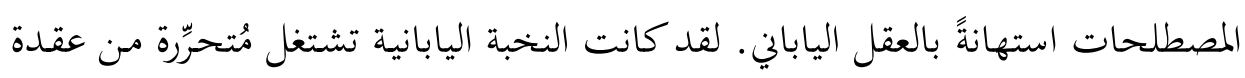
الآخر، ومثل هذا الفعل الاحترازي لا يزال يلازمها.

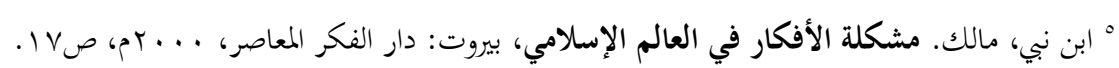

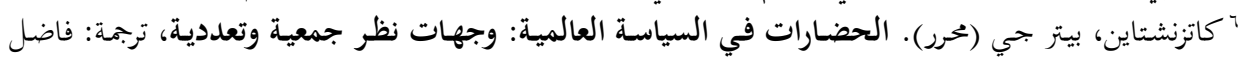

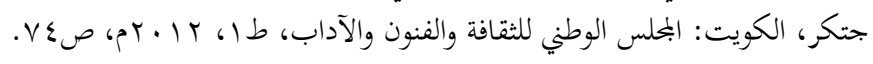


وقد انمازت النخبة اليابانية بحسّ حضاري أسهم في التفريق بين الداخل في صورة

أفكار قابلة للنقـد والمراجعـة والإضـافة والإفـادة، والدـخيل في صسورة أسماء ومصطلحات

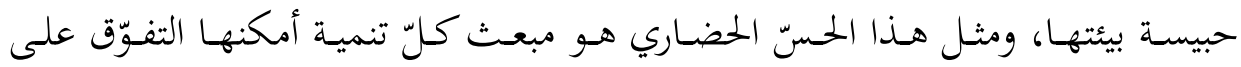
المستفاد منه. ففي الوقت الذي كانت فيه الصين غارقةً في الآداب كان اليابانيون عاكفين على إبداعات مستقبلية؛ إذ توجّهت النخبة اليابانية إلى تعلّم اللغة الهولندية على امتداد

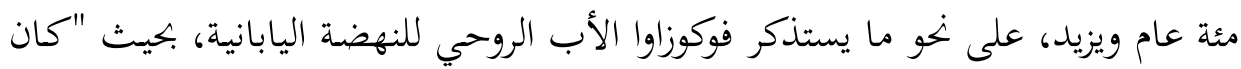
على الراغبين في دراسـة علـم المدفعيـة القيـام بـذلك وفقـا لـنهج الهولنـيين، الـذين كـانوا

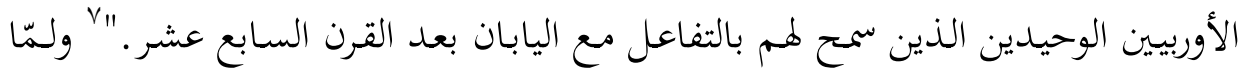

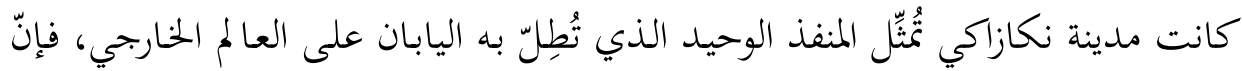
العزلة كان فيها شيء من الحضارة؛ فهي لمج بحرِ قطيعةً مطلقةً مع العالم. لقد كانت هناك

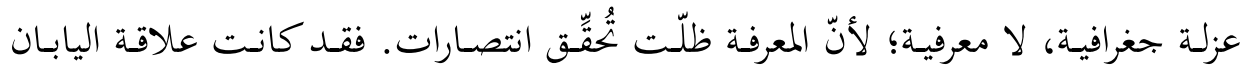
بالصين "ثقافية واقتصادية أكثر، سياسية أقل، وعسكرية معدومة بالمطلق، إضافة إلى أن

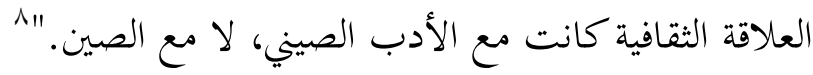
ولا شكّ في أنّ أهم ما ميّز فترة العزلة هو ذلك البُعْد الحضاري في المعركة الذي كان

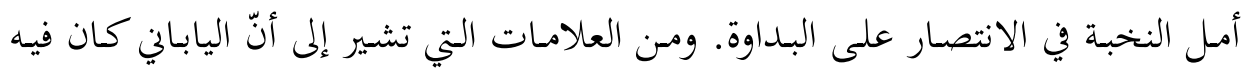

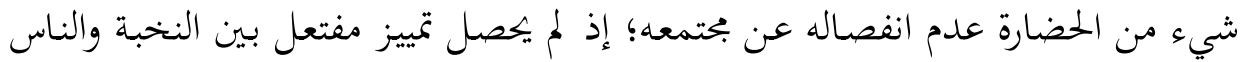

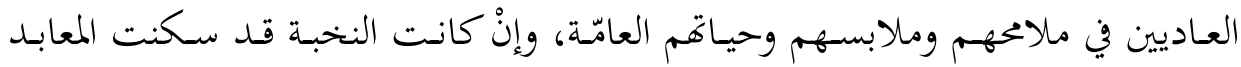

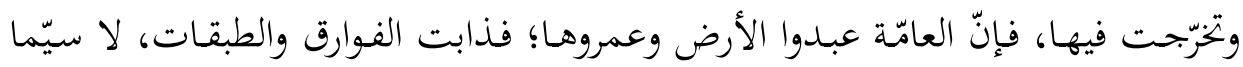
بين النخبة والفلاحين.

لقـد شَكَّل هـذا التفاعل أول مـداخل الحضـارة؛ إذ التحضّر هـو "أن يتعلم الإنسـان

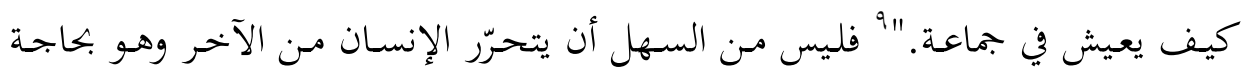

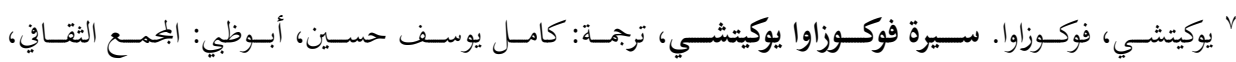
r Tr

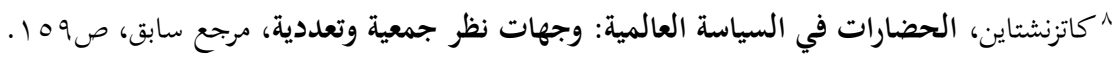

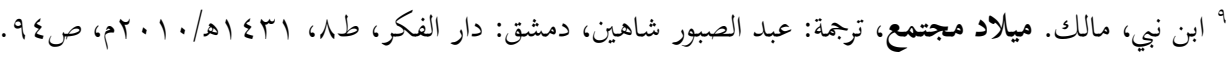




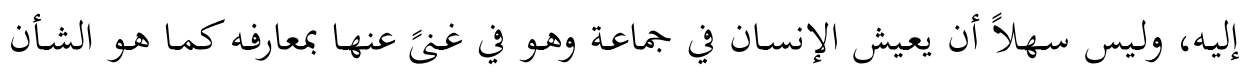

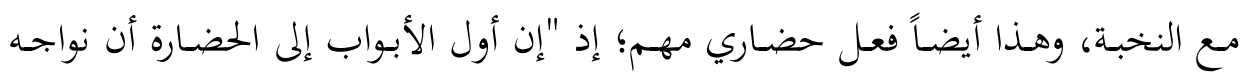

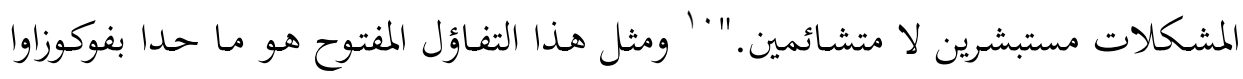

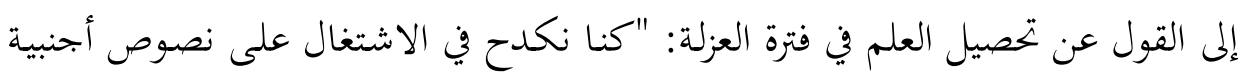

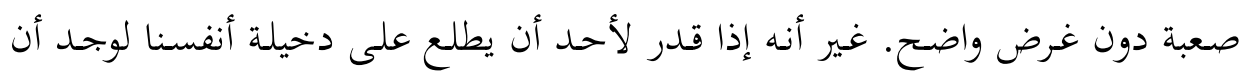

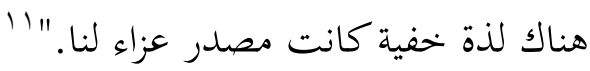

إنّ العيش في جماعة هو الذي دفع فوكوزاوا إلى الاعتراف، قائلاً: "لم يكن بناحي

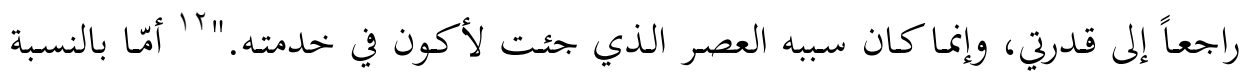

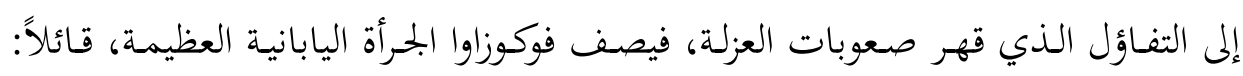

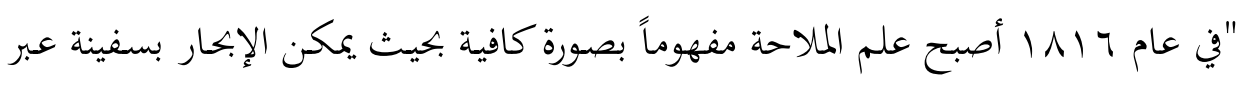

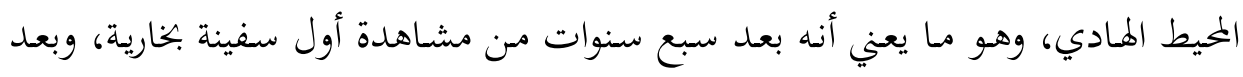

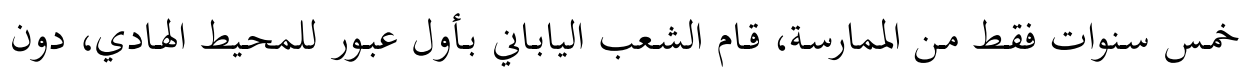

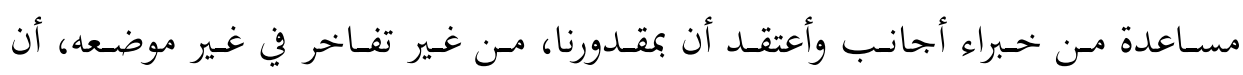

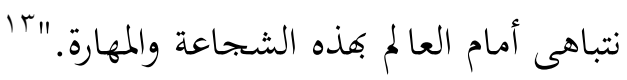

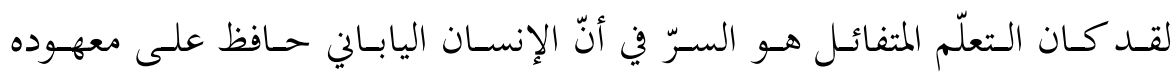

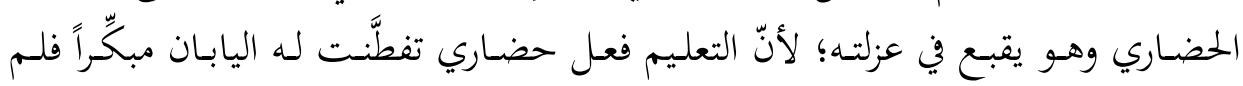

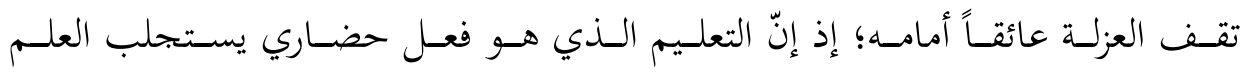

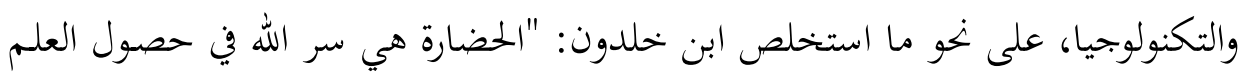

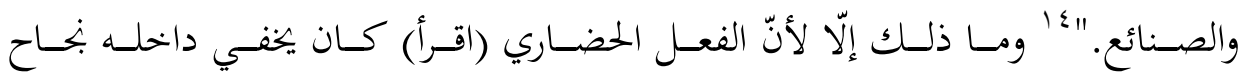

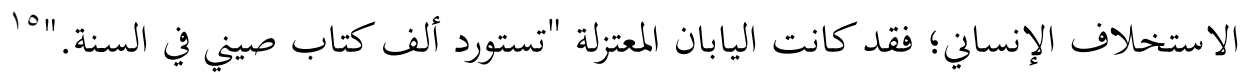

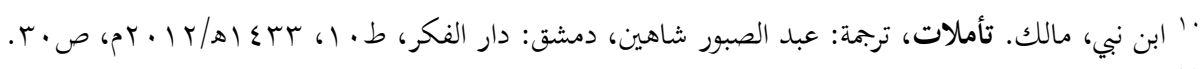

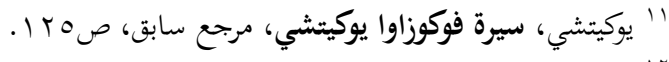

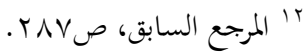

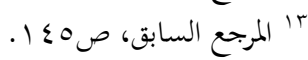

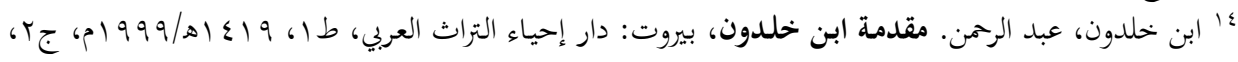
• كاتزنشتاين، الحضارات في السياسة العالمية: وجهات نظر جمعية وتعددية، مرجع سابق، ص017. 


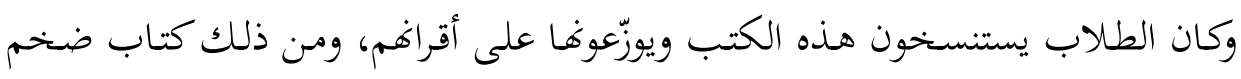

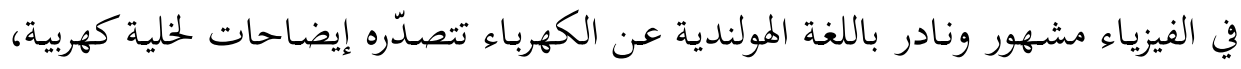

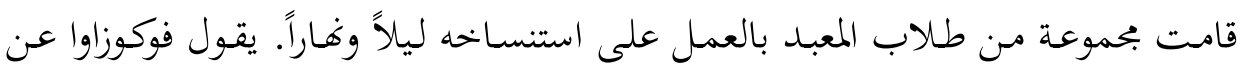

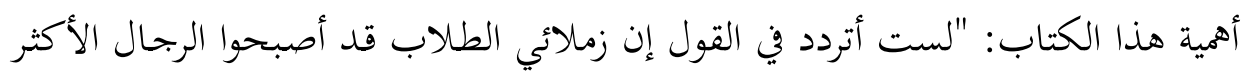

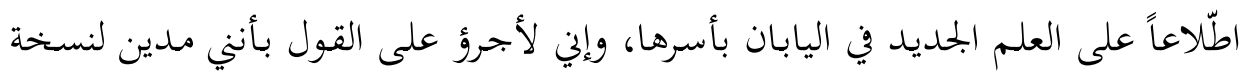

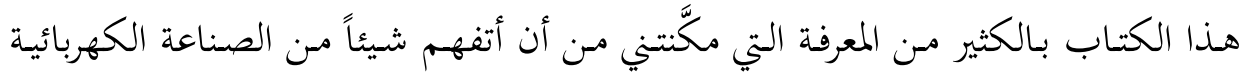

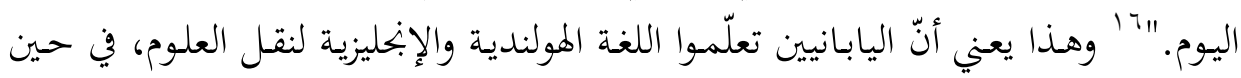

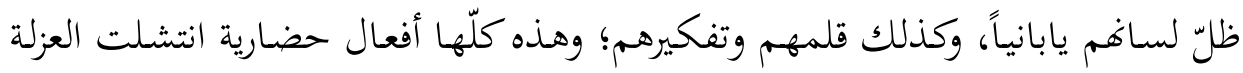
من المسار غير الحضاري الذي قد تقع فيه أيّ عزلة.

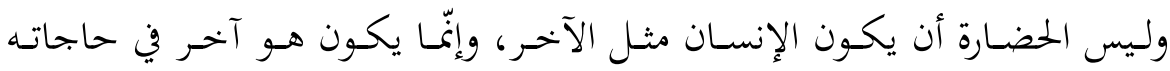

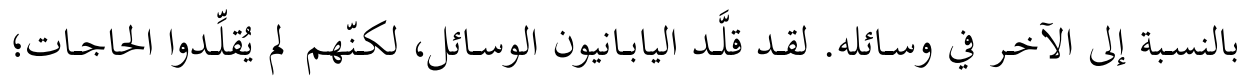

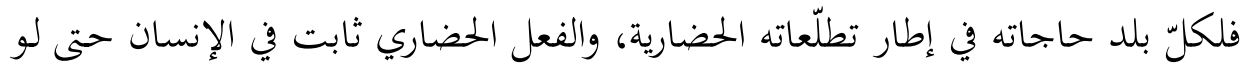

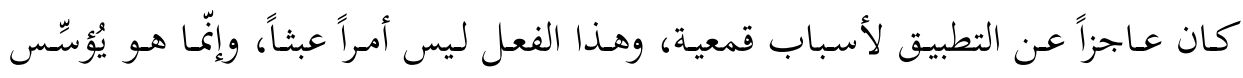

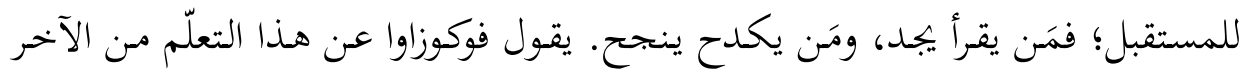

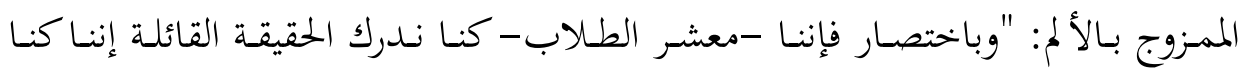

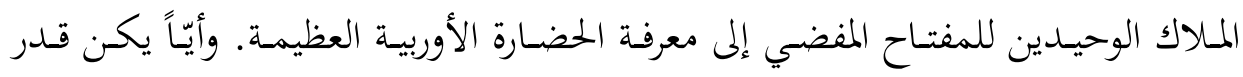

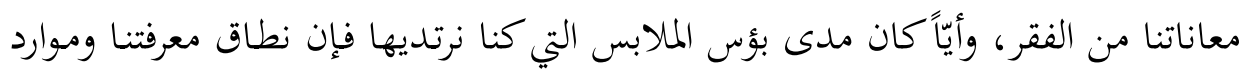

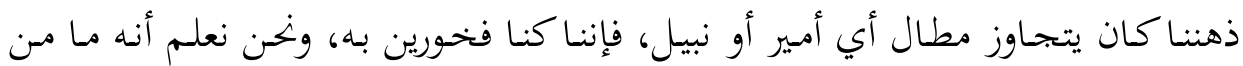

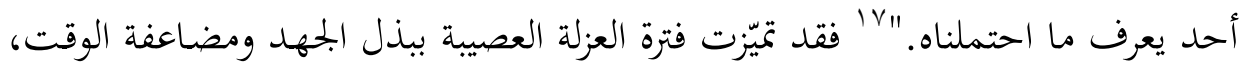

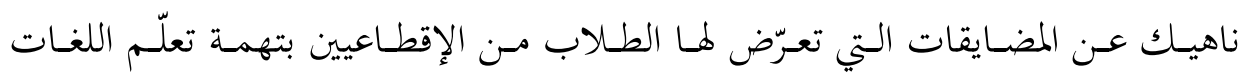
الأجنبية.

ومهع أنّ الإقطاعيين كانوا على قـدر مـن المعرفـة، إلّا أنّ معرفتهم لم تكـن إنسـانيةً،

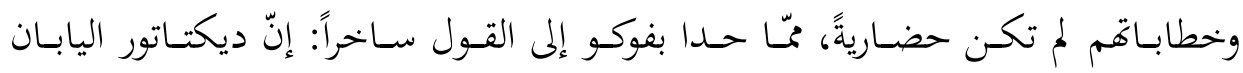


شـوغون في القـرن الثـامن عشـر المـيلادي سمـع "عـن مـلاح إبنحليزي كـان يمتلك سرّ هـذه الخطابات استقدمه إلى قصره وأبقاه عنده حيث تلقى منه على انفراد دروساً. لقد تعلم الحاكم الرياضيات واحتفظ بعدها بالسلطة وعاش طاعنا في السن، أما اليابان فلم يتوفر

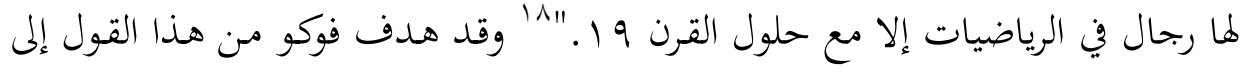
تأكيد أنّ الاستبداد الشرقي وبداوته يحتكران الخطابات المعرفية.

ومع ذلك، فإنّ هذه البداوة كان فيها شيء من التحضُّر، لا سيّما اهتمام توكوغاوا

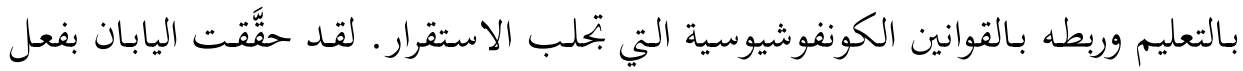

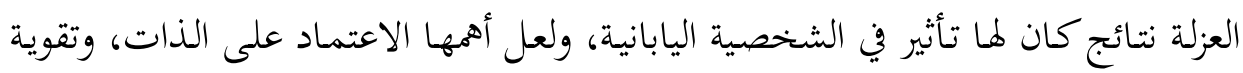

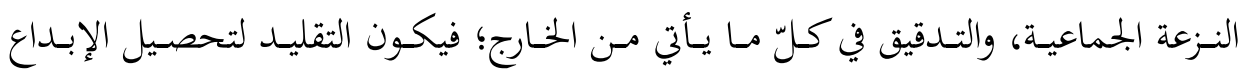

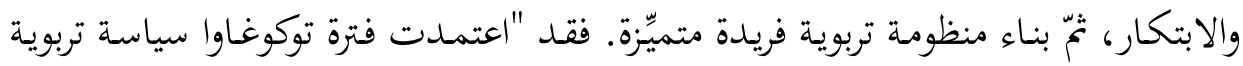

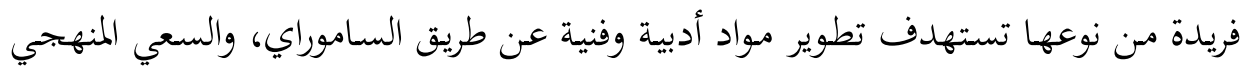

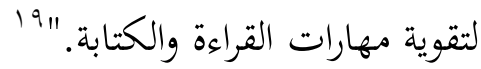

وقـد أسهمت العزلـة في زيـادة الإنتاجيـة، وذلكك بتكثيـف الجهــ، فضـلاً عـن توجيـه

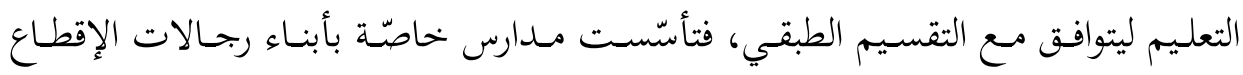

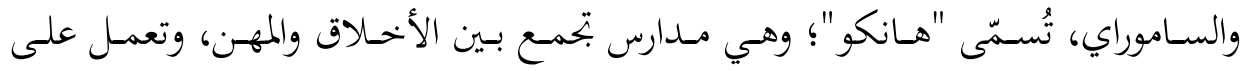

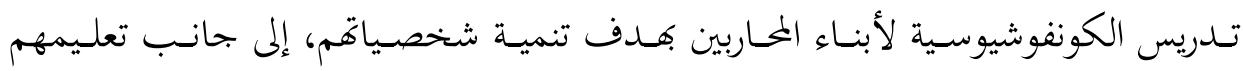
المهارات الإدارية والحربية. وقد انتشرت هذه المدارس بحيث بلغت ثلاثمئة مدرسة في يختلف أرجـاء اليابـان، وكان ذلك قبـل منتصف القرن التاسع عشر الميلادي. أمّا مـدارس المعابـد

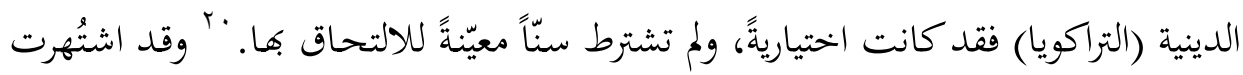

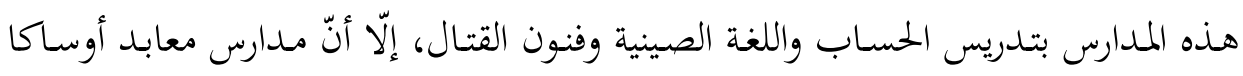
^1 فوكو، ميشيل. جنيالوجيا المعرفة، ترجمة: أحمد السطاتي، وعبد السلام بنعبد العالي، الدار البيضاء: دار توبقال

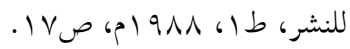

${ }^{19}$ Duke, Benjamin. The Japanese School: lesson for Industrial America, London: Westport, Connecticut, 1986, p 61.

${ }^{20}$ Marshal, Byron K. Learning to Be Modern: Japanese Political Discourse on Education, Oxford: Westview Press, 1994, p18. 
جمعت بين اللغة الصينية والهولندية؛ نظراً إلى قرب أوساكا من نكازاكي. وقد برع فوكوزاوا

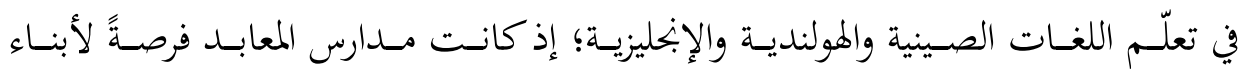

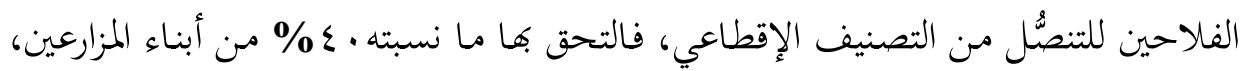

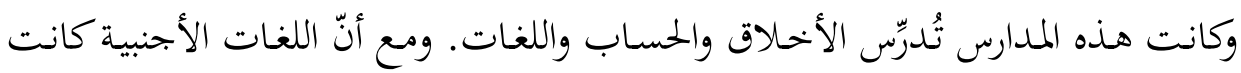
هامشيةً، إلّال أغّا أسهمت في إثراء حقاء حقل الترجمة.

وإلى جانـب مـدارس المعابـد التي انشغل طلابهـا بالطب والرياضيات والفيزياء وعلم

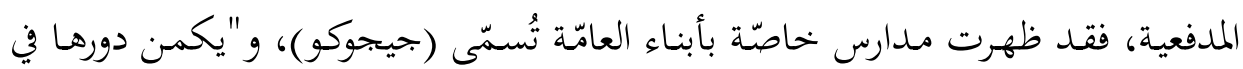
تشجيع الطلاب على إثارة الأسئلة في قضايا دينية ظلت حكراً على الطبقة المتعلمة مـن

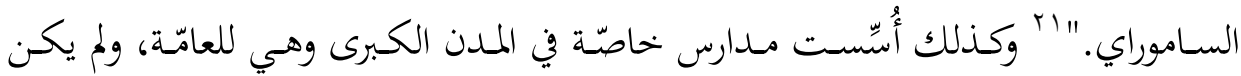
يسمح للبنات بدخول المدارس عدا مدارس المعابد، أو المدارس الخاصّة. ومن ثئَّ "فإن نسبة

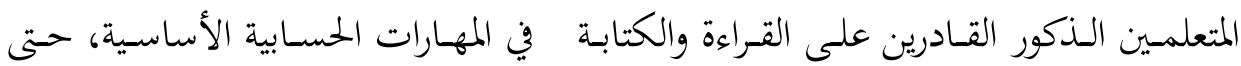

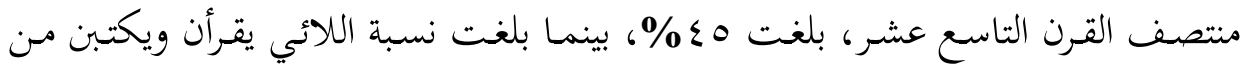

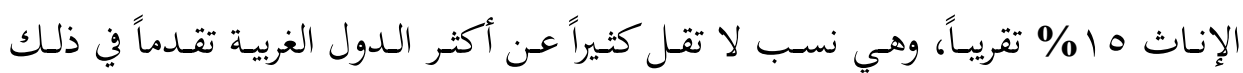

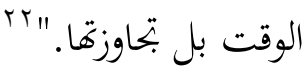

وقـد انتشرت أيضـاً ظاهرة التعليم في المخـازن، وهي خحاصّة بالأطفـال الصغار الذين تتراوح أعمارهم بين (T ا (T I) سنةً، والذين لم يكملوا تعليمهم لظروف مادية. ومعظم هؤلاء الأطفال (يُطلَق عليهم اسم هوكونين) كانوا من أبناء التجار والطبقات الوضيعة، وقد

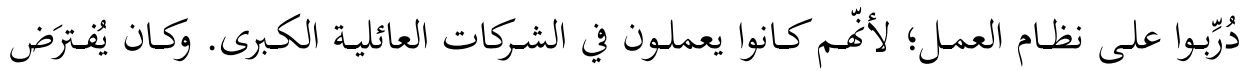

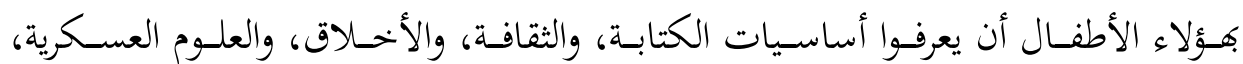
والعمليات الحسابية، وأن يكتسبوا المهارات اللازمة قبل الالتحاق بالشركات.

${ }^{21}$ Simmons, Cyril. Growing up and going to School in Japan: Traditional and Trends, Philadelphia: Open University Press, 1990, p 11.

${ }^{22}$ Kuroda, Kazuo. "Educational Development Experience", in: Toyado, Toshihisa et al. (eds.). Economic and Policy Lessons from Japan to Developing Countries, New York: Palgrave Macmillan, 2012, p148. 


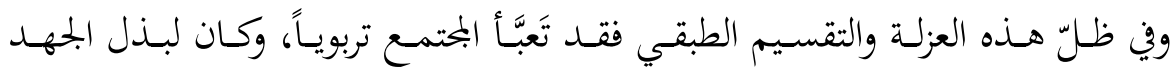

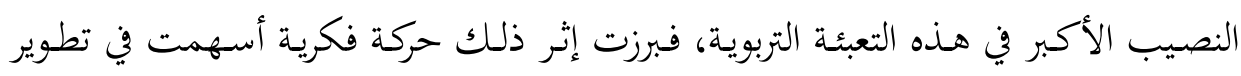

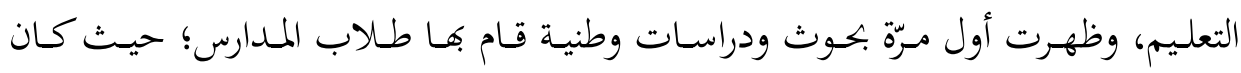

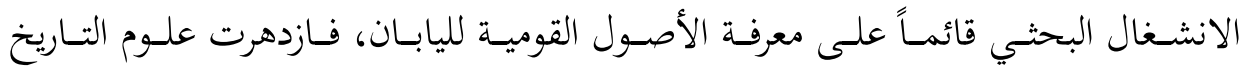
واللسان، تُّ علوم الفيزياء والكيمياء والرياضيات والخرائط.

لقد درج الإنسان الياباني على امتلاكك الحسّ الحضاري الذي نستشفّه مـ مسايرته

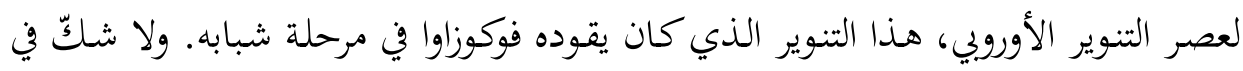

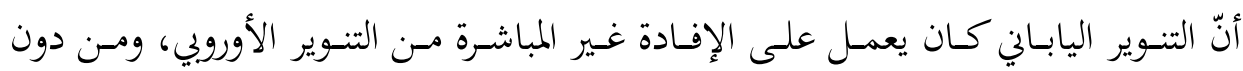

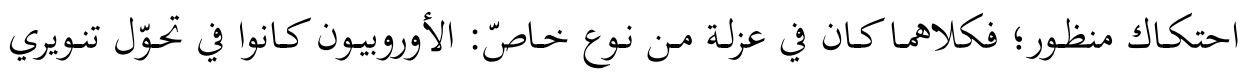

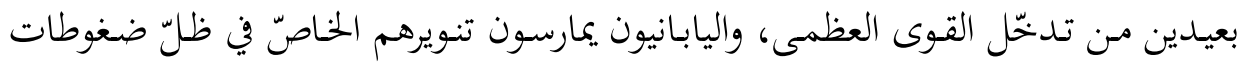

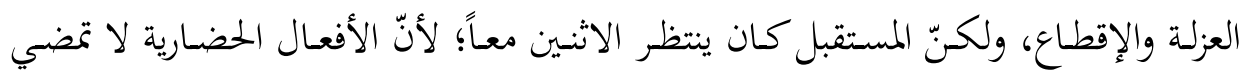

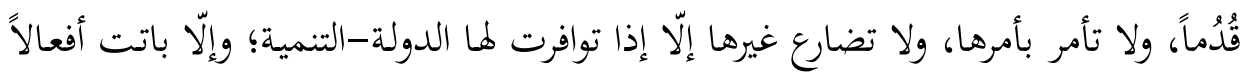

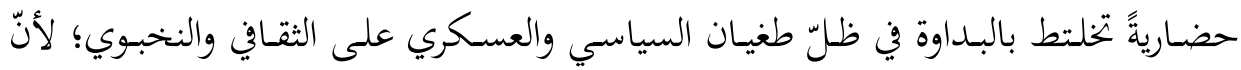

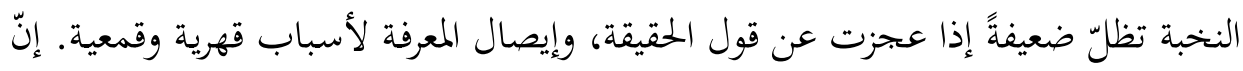

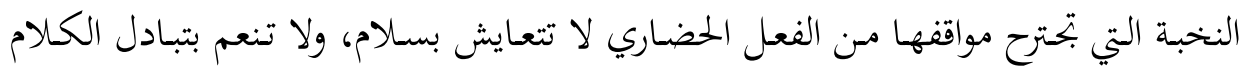

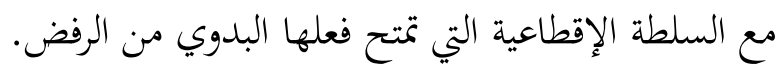

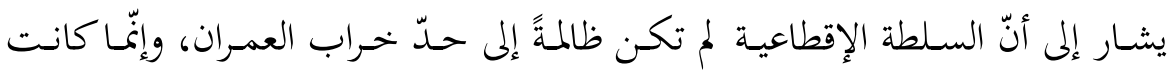

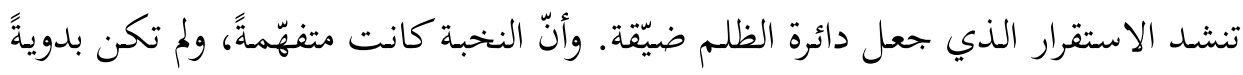

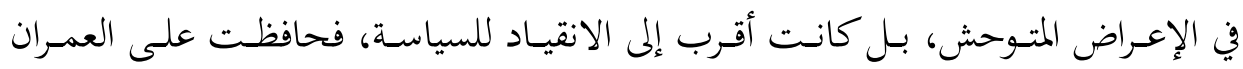

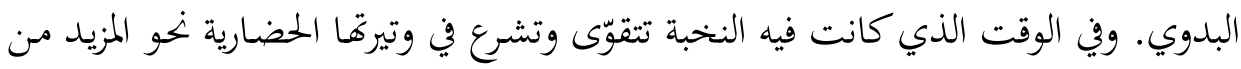

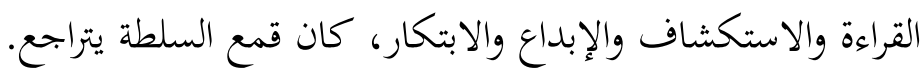
وما من شكُّ في أنّ معالم الدولة-التنمية كانت تتشكّل داخل هذا الصراع بين بداوة

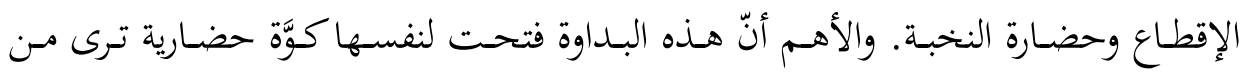

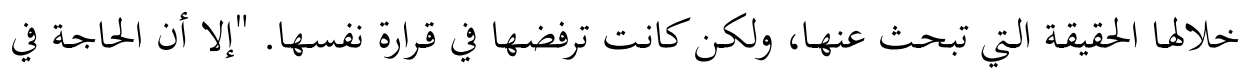




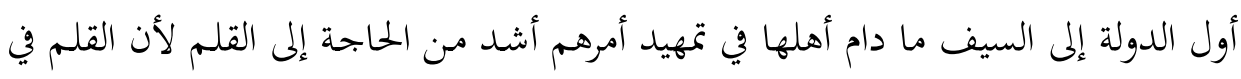

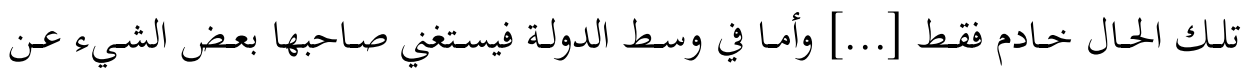
السيف لأنه قد تمهد أمره ولم ييق همه إلا في تحصيل ثمرات الملك.

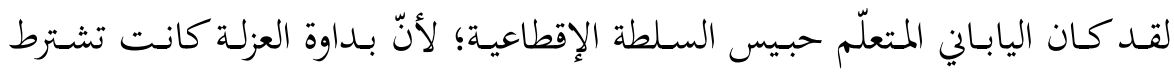

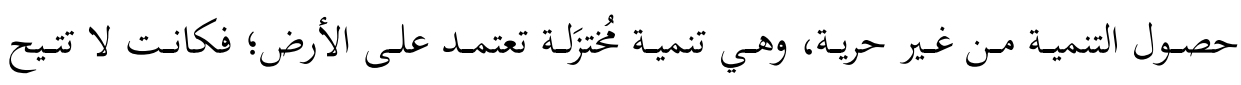

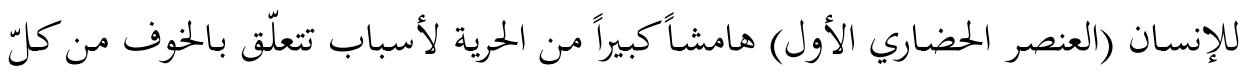

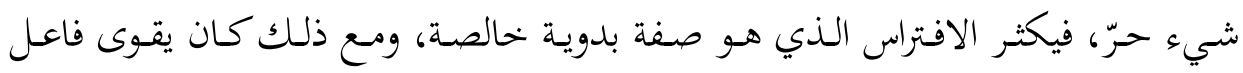

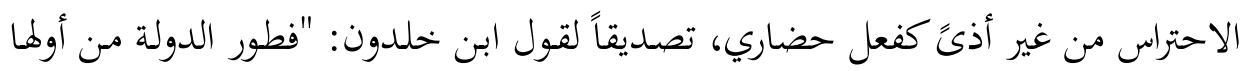

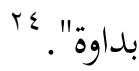

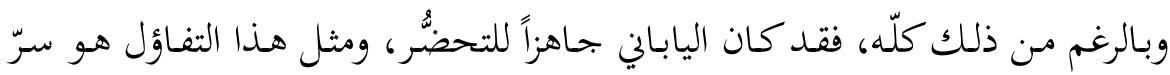

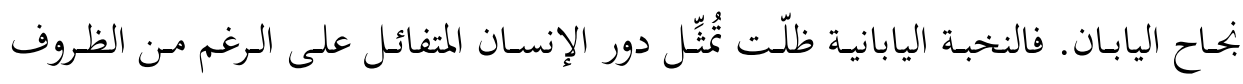

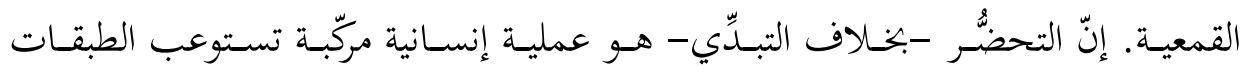
والفوارق، وتستقطب المهارات والخوارق. وهو طريق حضاري ظلّ يتكشَّف لليابانيين يوماً بعد آخر.

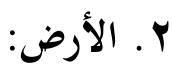

التراب بالنسبة إلى ابن نبي هو المادة، أو المواد الأولية، أو الأرض. وقد كان توكوغاوا

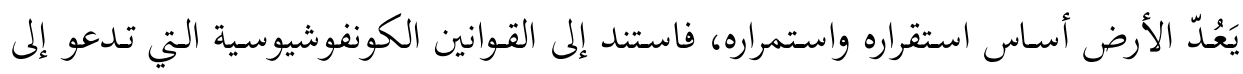

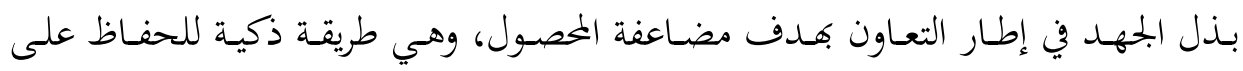

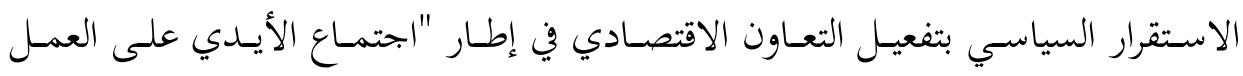

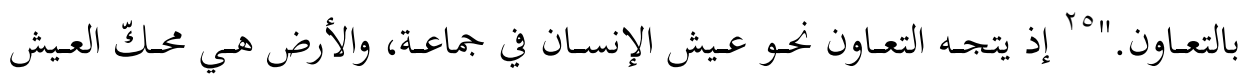

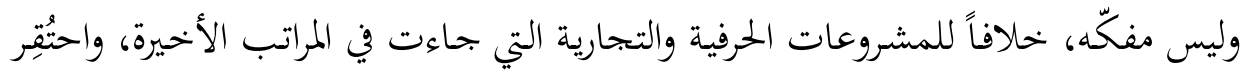

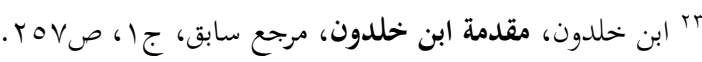

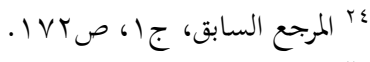

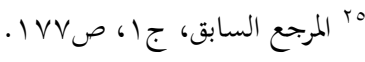




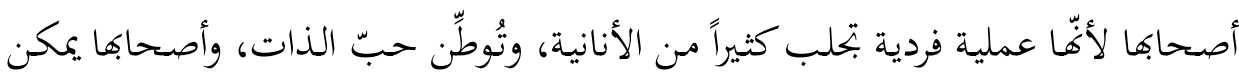

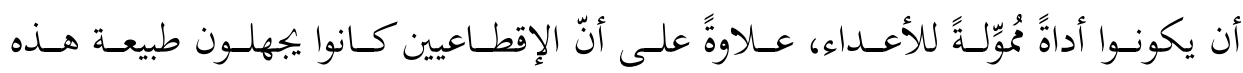

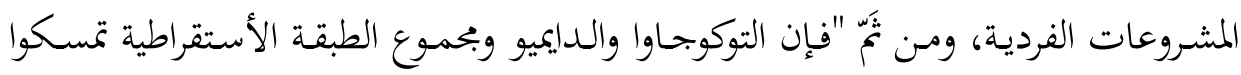

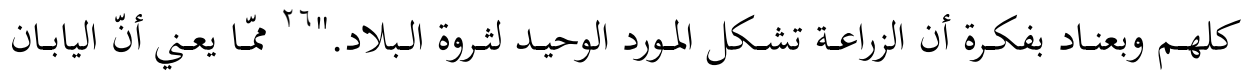

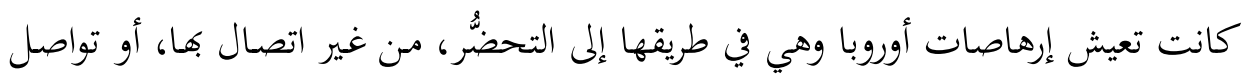
في أمور اقتصادية.

وهذا يعني أنّه كان يُنظًر إلى الأرض بوصفها مورداً مالياً مهماً للحفاظ على الاستقرار

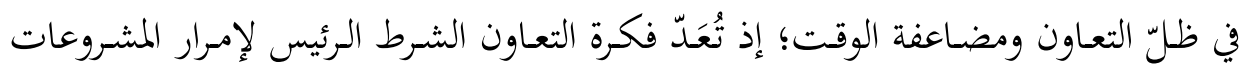

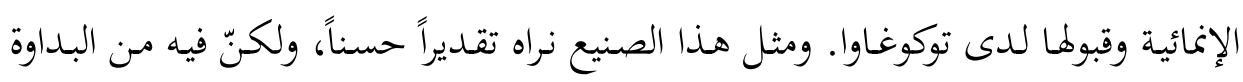

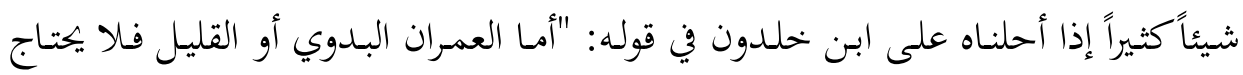

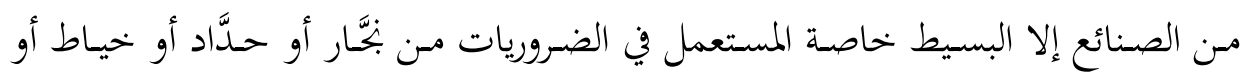

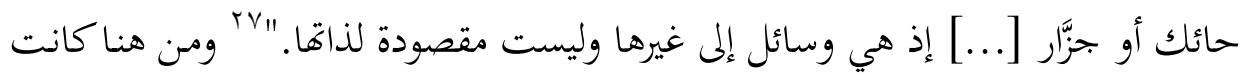

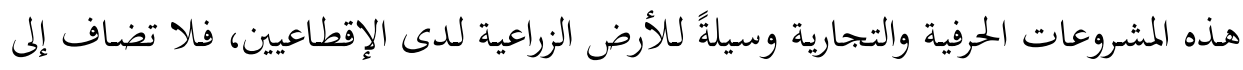

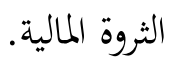

إنّ البحث عن تراكم المال كان غاية الإقطاعيين، والأرض كانت أهمَّ وسيلة لغاية

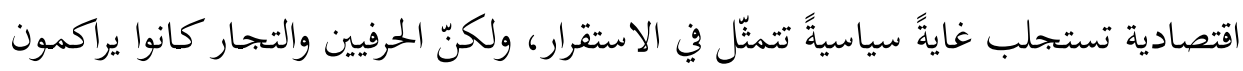

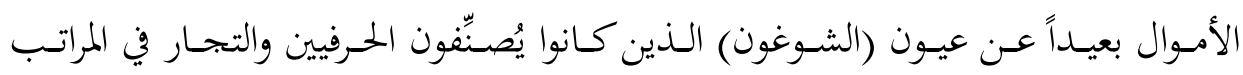

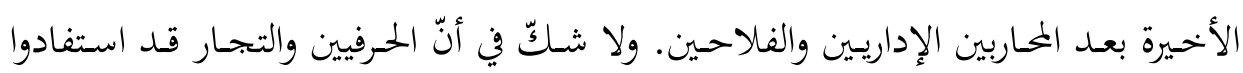

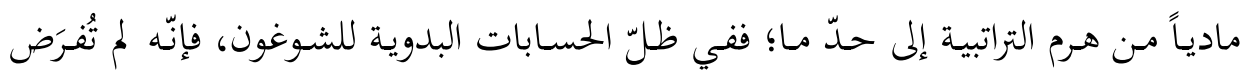

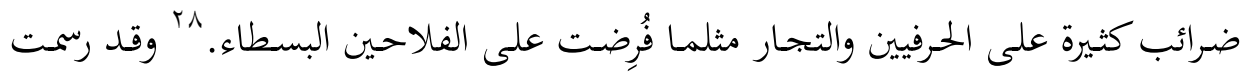

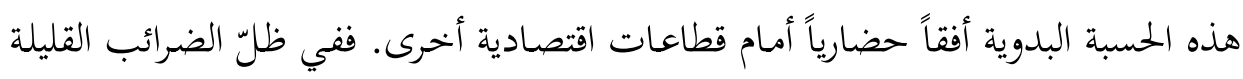
"rايشاور، أدوين. تاريخ اليابان من الجذور حتى هيروشيما، ترجمة: يوسف شلب الشام، دمشق: منشورات دار

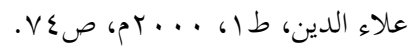

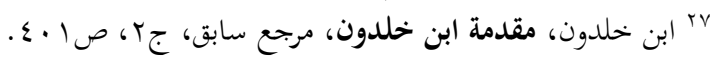

${ }^{28}$ Macpherson, W. J. M. The Economic Development of Japan 1868-1941, Cambridge: Cambridge University Press, $p 18$. 


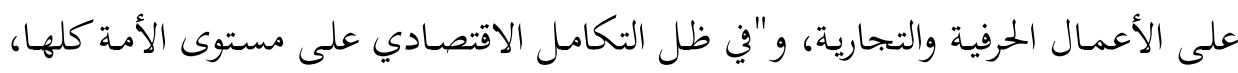

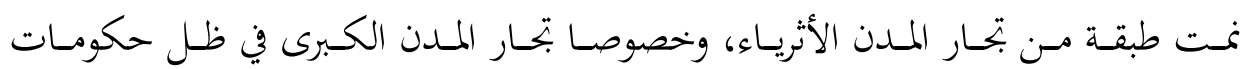

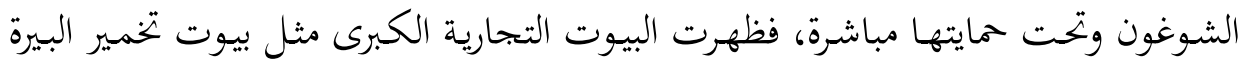

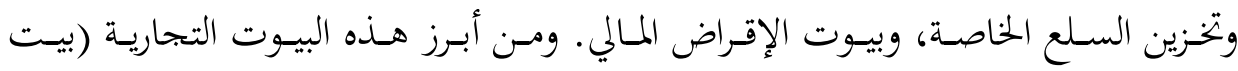

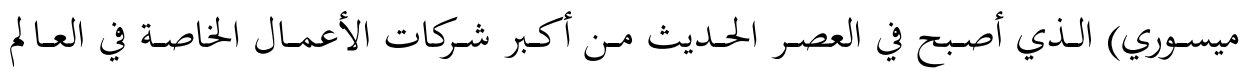
كله."

لقد بدا التراب التوكوغاوي فاعلاً؛ لأنّ الفعل الحضاري كان ماثلاً، وإلّاّ لكان ضُيِّق

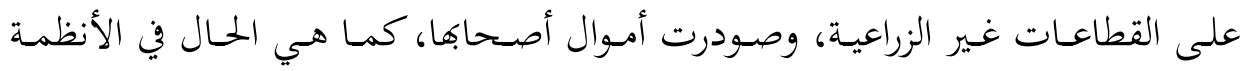

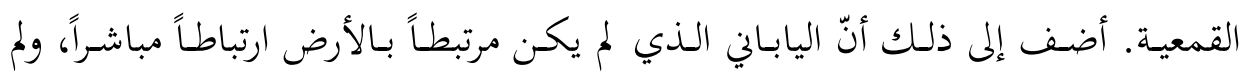

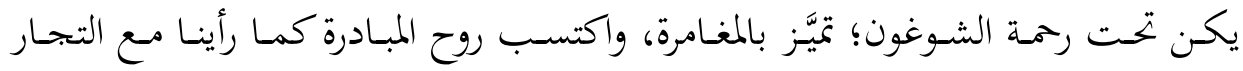
والصناع؛ فهؤلاء كانوا يخلقون التوازن داخل القطاعات الاقتصادية غير المتوازنة. وقد تميَّز

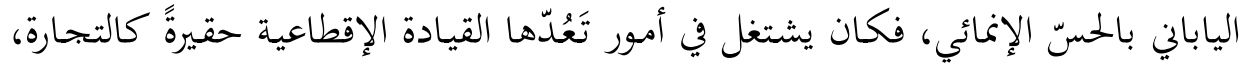

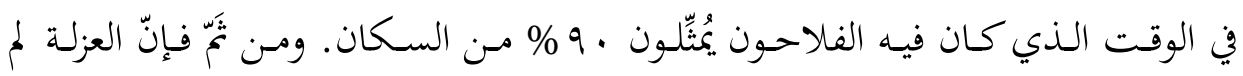

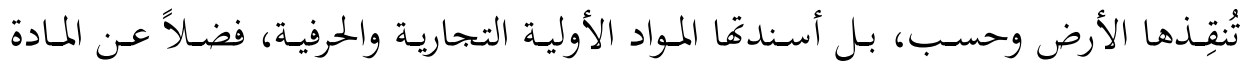

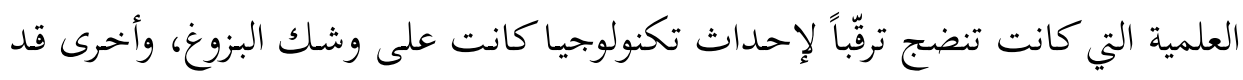

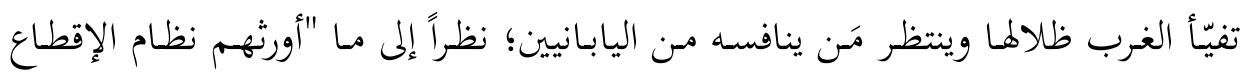

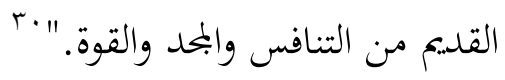

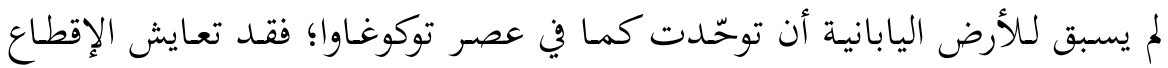

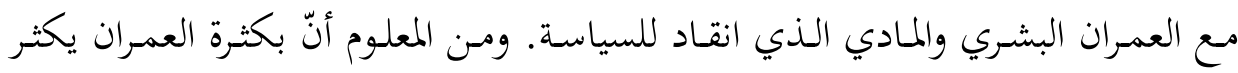

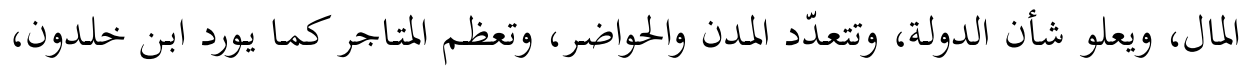

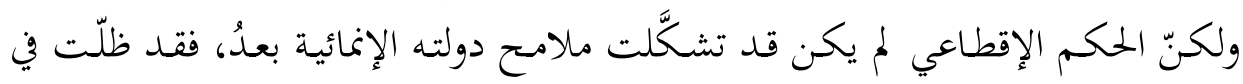
ج" رايشاور، أدوين. اليابانيون، ترجمة: ليلى الجبالي، الكويت: البحلس الوطني للثقافة والفنون والآداب، 919 (م)، • أرسلان، شكيب. لماذا تأخر المسلمون ولماذا تقدم غيرهم؟، بيروت: منشورات دار مكتبة الحياة، د.ت، 


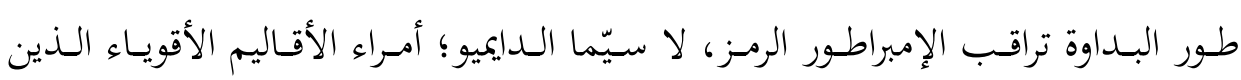

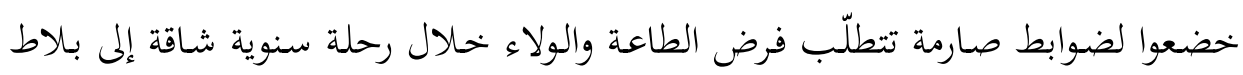

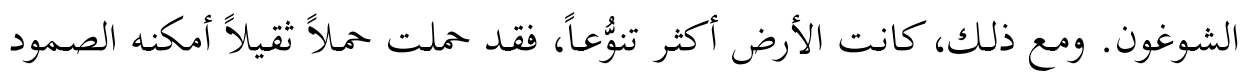

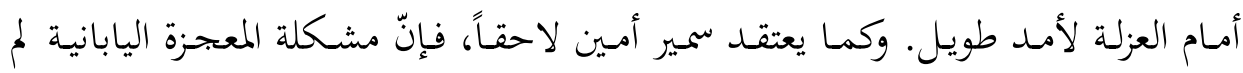

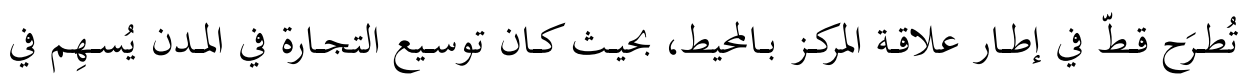
تفكّك العلاقات الإقطاعية، يقول: "في اليابان كانت الظروف البيئية تضع أمامه حواجز جدية: فقد كان تقطيع الأرض الإقطاعي كما كانت استقلالية المدن التجارية يحدان من مركزة الدولة لدرجة أن التشابه بين اليابان وأوربا، رغم آلاف الكيلومترات، يثير الدهشة.

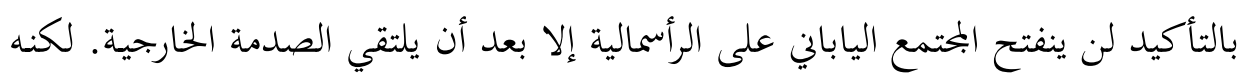

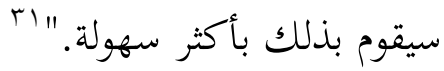

ويَ ظلّ هـا التقـدّم شعر الإقطاعيون أنّ الوضع القـائم يحتـاج إلى قليل مـن الحريـة. ففي "يابان توكوغاوا كان عنصر الشعب والأرض موحَّدين (كوكَّا)، غير أن تمايزاتٍ مهمة الإنة سياسياً ما فتئت أن ظهرت في إطار ذلك التصور التقديسوي، بين ما هو رسمي وما هو

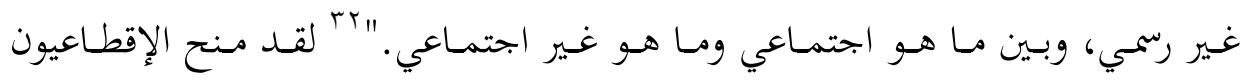

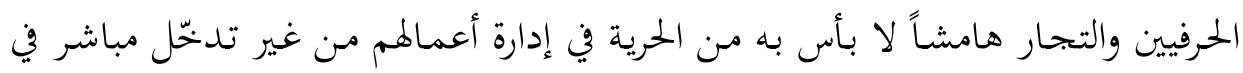
شؤوهم، أو التعدي عليهم من غير أسباب واضحة. فما كاد قرن العزلة يتصرَّم حتى بلغ التراكم الاقتصادي درجة يضاهي تراكم الدول المتطورة، ممّا جعل الأرض تتهيأ بجدارة إلى لى

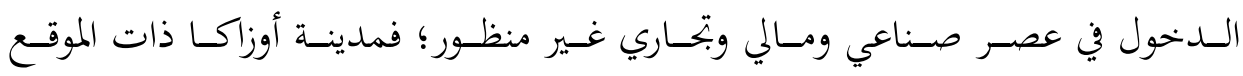
الاستراتيجي "ارتقـت إلى مرتبة المرفأ التجاري الأول لليابان الغربية؛ حيث وبن بنى فيها كثير

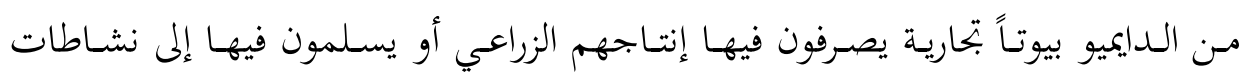

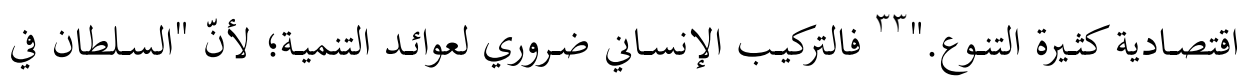

ابr أمين، سمير. النطور اللامتكافئ: دراسة في التشكيلات الاجتماعية للرأسمالية المحيطة، ترجمة: برهان غليون،

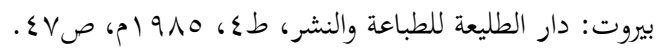

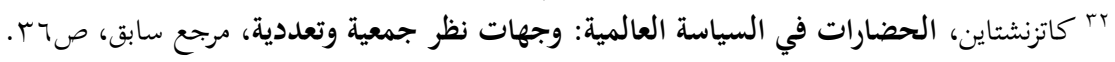

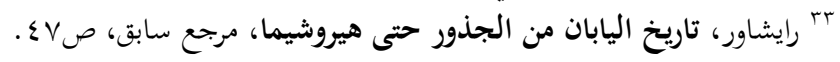


نفسه ضعيف يحمَّل أمراً ثقيلاً فلا بـدّ له مـن الاستعانة بأبناء جنسه. وإذاكان يستعين

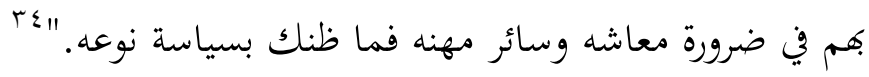

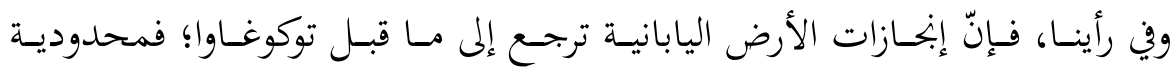

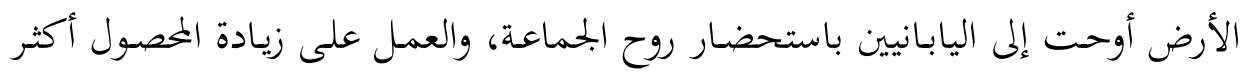

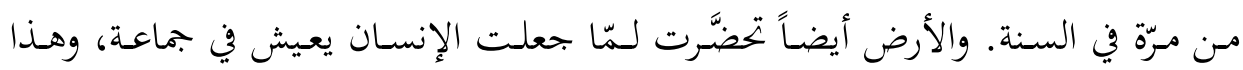

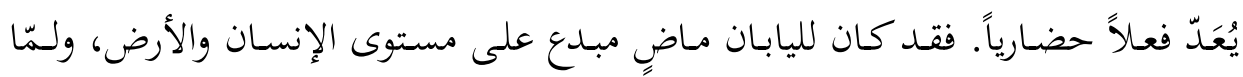

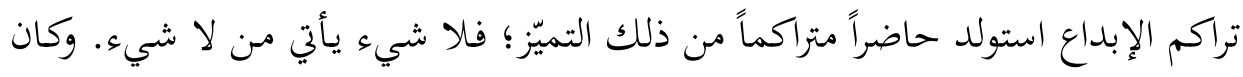

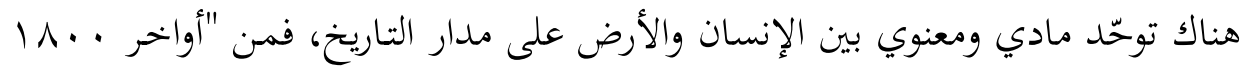

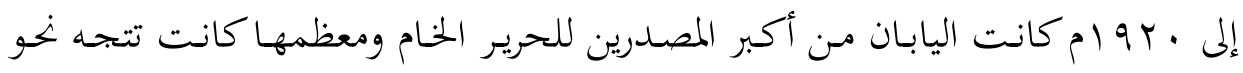

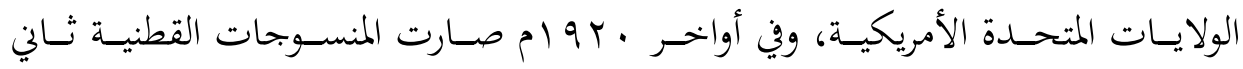

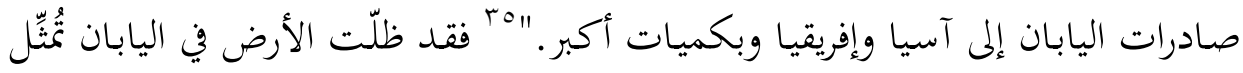

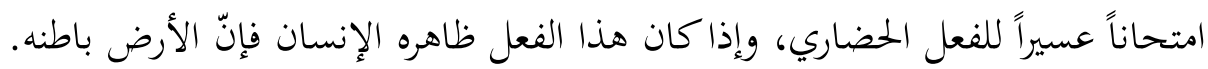
وقد يستورد الإنسان أفعاله الحضارية في صورة وسائل عن طريق الاحتكاك بوسائل

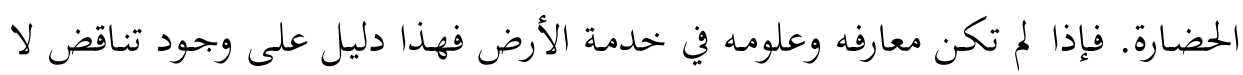

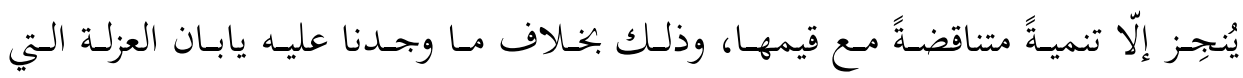

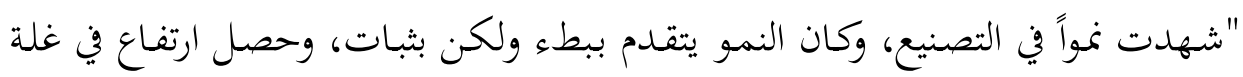

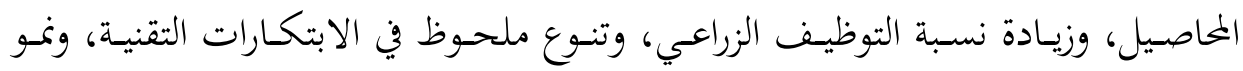

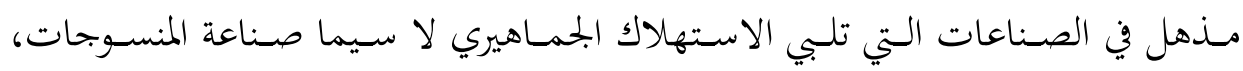

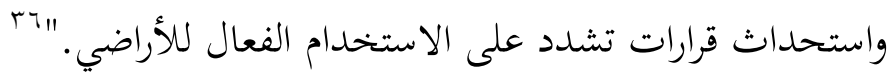
وتأسيساً على ما سبق، حين تكون الأرض متخلّفة، فإنّ التنمية المستوردة لا تذهب بالإنسان بعيداً، فينتقم الوقت؛ لأنّ وقت هذه التنمية يكون حينها قد احتلّ وقت تندية

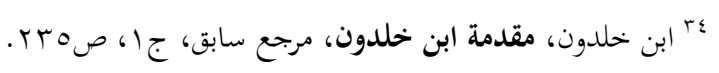

${ }^{35}$ Takafusa, Nakamura. Lectures on Modern Japanese Economic History 1926-1994, Tokyo: LTCB International Library Foundation, 1999, p10.

${ }^{36}$ Smith, Thomas C. Native Sources of Japanese Industrialization, 1750-1920, California: University of California Press, 1980, p16. 


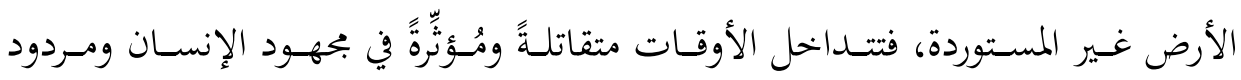

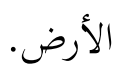

\section{r. الوقت:}

كلّما امتدت القيم الأخلاقية أصيلةً في البمتمع كان الوقت فاعلاً. فالوقت يضيع غالباً

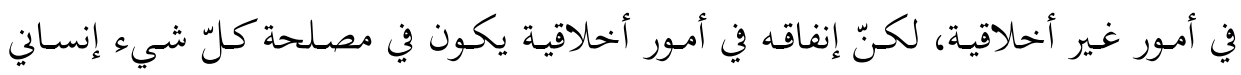

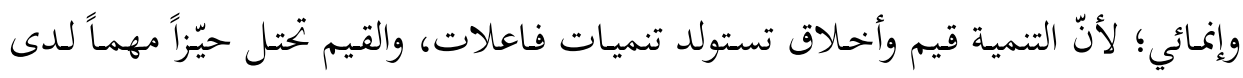

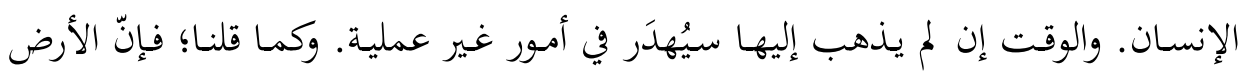

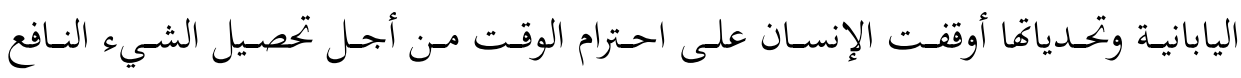

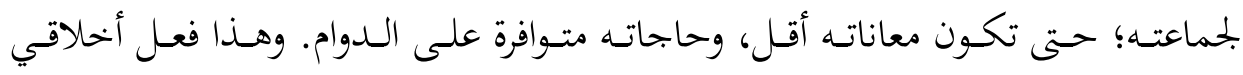

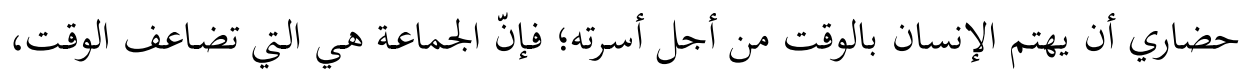

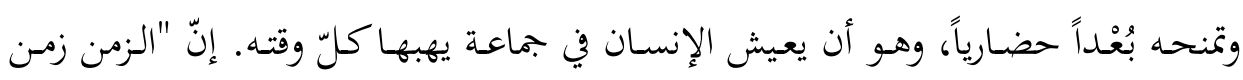

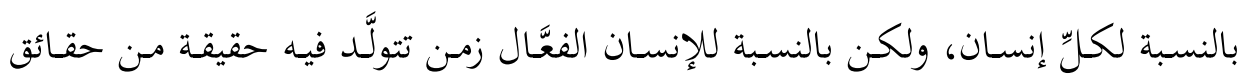

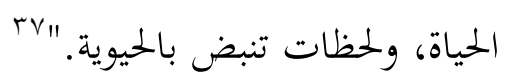

أمّا الوقت بالنسبة إلى اليابانيين فلم يكن الزمن المُقعَّرَ بالساعات؛ وإلّال فإِنّ العزلة لم

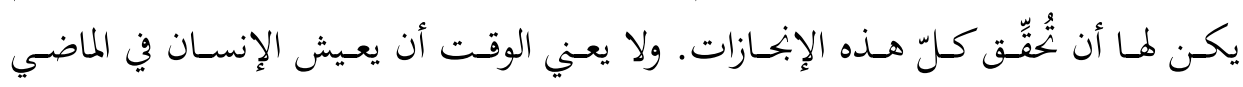

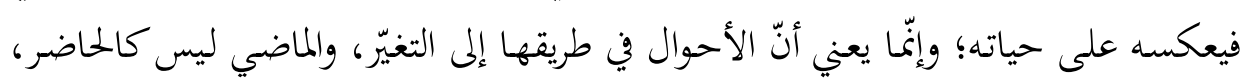

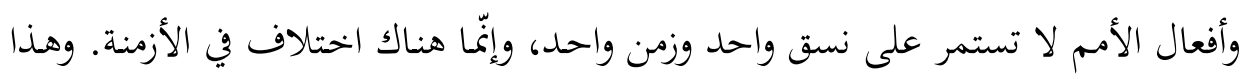

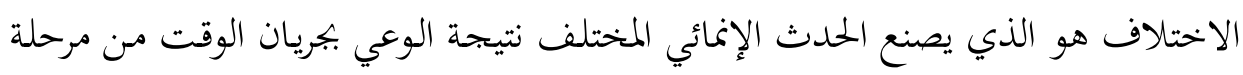

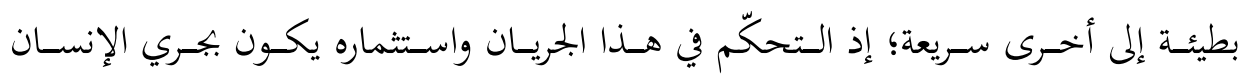

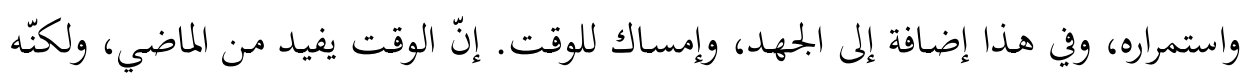

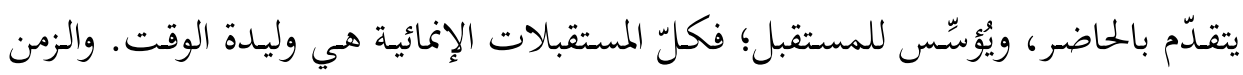

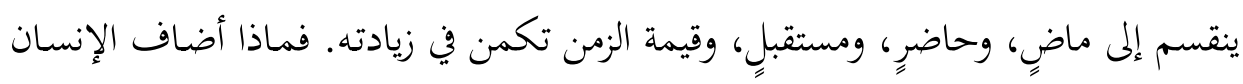

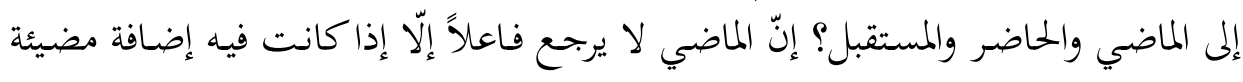


يمنحها الحاضر بوقته المضاعف، والحاضر لا يكون نافعاً إلّا إذاكان وقته المرئي إنمائياً يسع المستقبل غير المنظور.

وتكمـن أهميـة اسـتثمار الوقـت في اليابـان في أنّه نقلهـا مسن ضـيق الجغرافيـا إلى ومسع

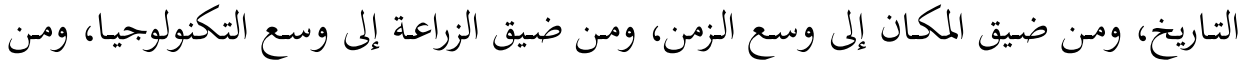

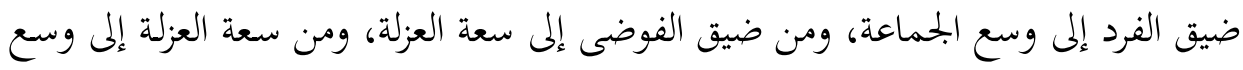

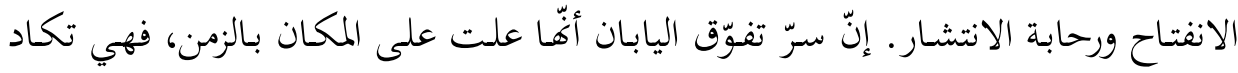

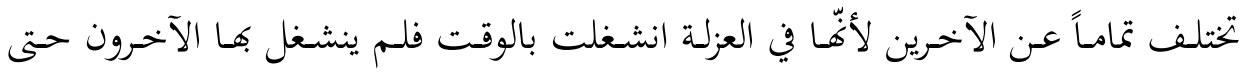

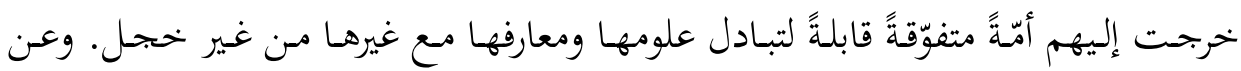

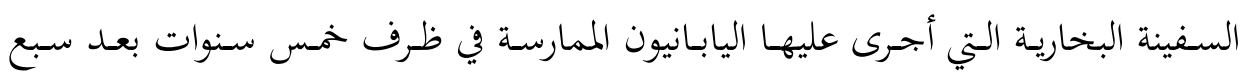

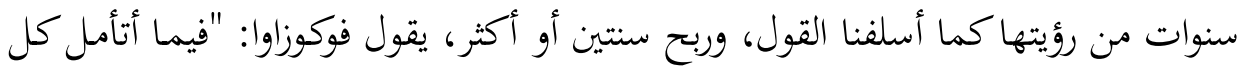

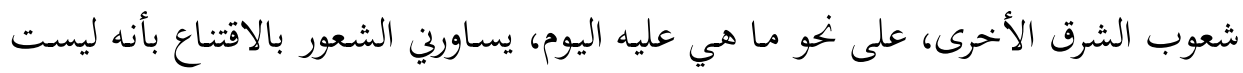

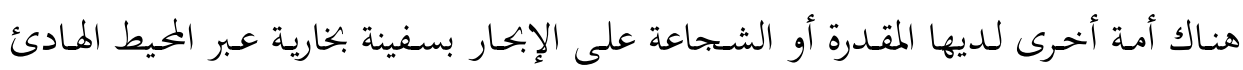

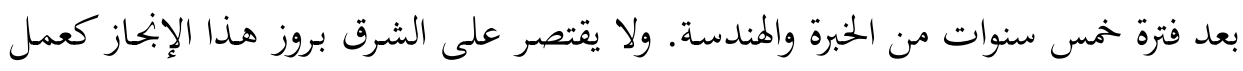

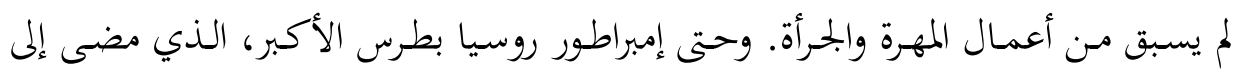

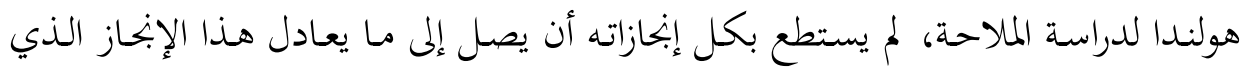

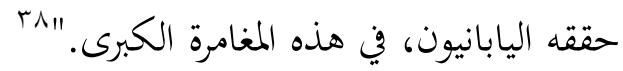

طبعاً أَولى اليابانيون الوقت جُلّ اهتمامهم، فهم دائماً يتعاملون مع المسائل بوصفها

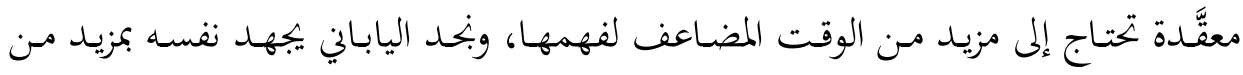

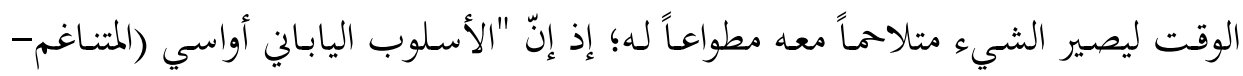

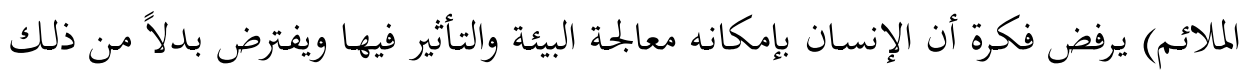

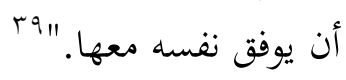

وقد تعلّم اليابـانيون أيضـاً كيف يفيدون مـن الوقت، وكيف ينتجون أكثر، ويوفّرون

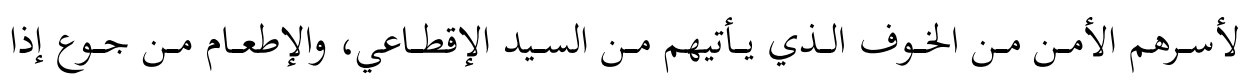

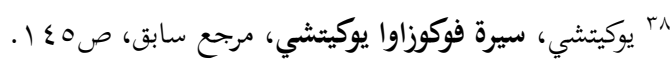

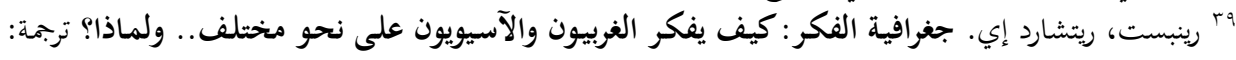

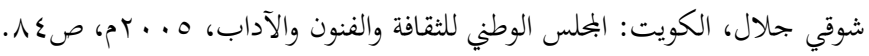




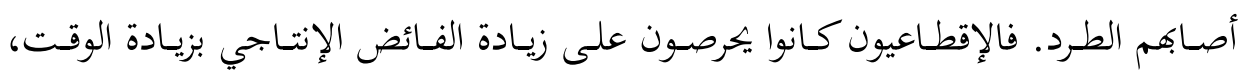

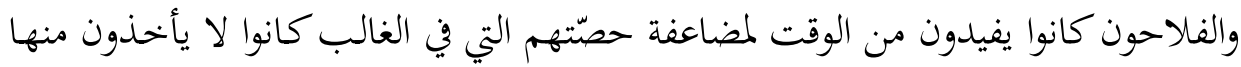

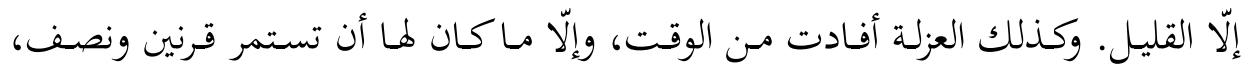

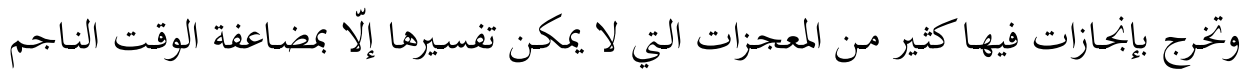

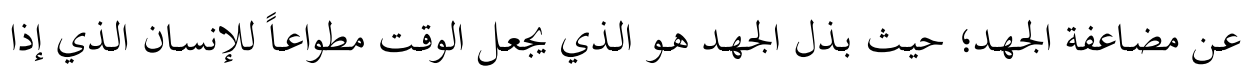

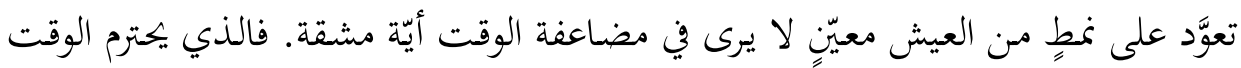

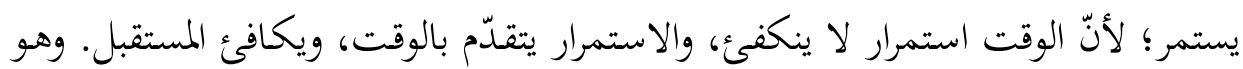

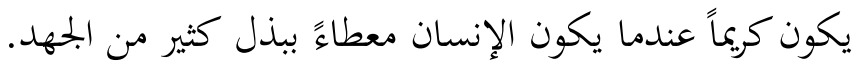

إنّ المسألة هي مسألة تعوُّد على الشيء، وما الوقت الإضافي إلّا عـادة متكرّرة تصبح

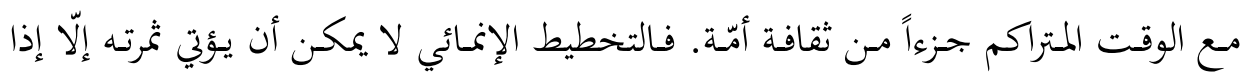
كان قد خرج من هذه الثقافة التي تَعُدّ الوقت أحد أركاهـا الحضارية. فكثير من الأعمال

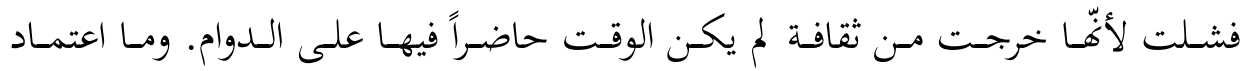

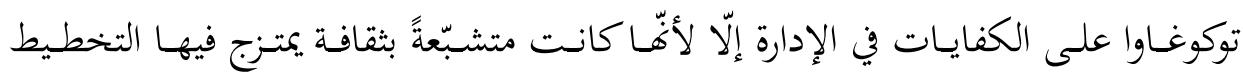
والوقت في تناغم فريد.

إنّ الذذين مارسـوا أعمـالهم وَفق أخـلاق معيّنـة حـافظوا على الوقـت وضـاعفوه. وقـد

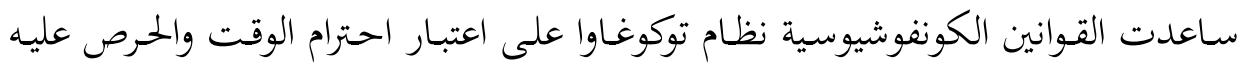

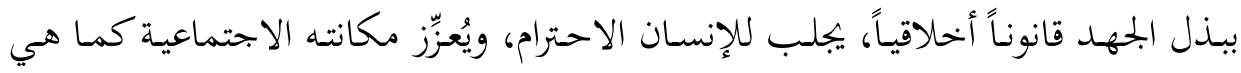
حال الحرفيين والتجار الذين لم ينشغلوا بمرتبتهم الوضيعة على حساب الوقت الذي كان

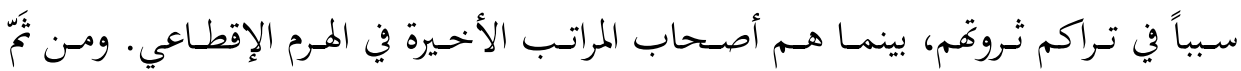

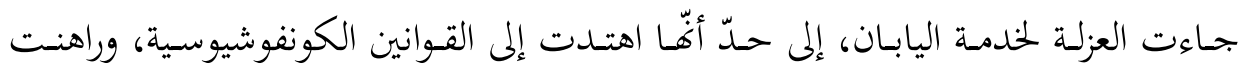
عليها في حفظ الأمن الذي استمر طويلاً، فوضعت اليابان على عتبة اللاعبين الاقتصاديين

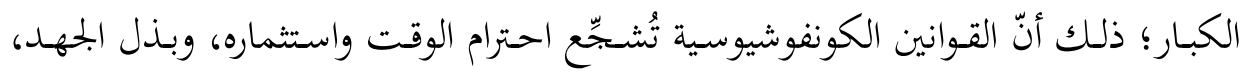
وتحقيق الانسجام، حيث كانت محل إعجاب روّاد التنوير الأوروبي مـن أمثال فولتير الرائد الفرنسي لنزعة حب الصين، الذي عاث في الفترة التي كانت فيها اليابان تتنوَّر في عزلتها. "إن الكونفوشيوسية بجحت في هيئة أساس لنظام أخلاقي واجتماعي، وهو النظام الذي 
بـدا أكثر فعاليـة وتأثيراً مـن نظيره في أوربـا." ·ـ فهل كان فولتير يدري أنّ الكونفوشيوسية

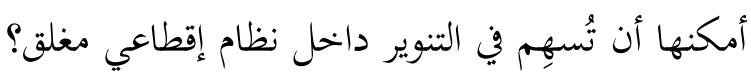
نعتقد أنّ هذا القمع لم يمنع اليابـانيين من تحصيل التنمية، ولكنّه كان عمراناً بـدوياً؛ لأنّ توكوغاوا تعامل مع نصوص الحضارة الصينية على مستوى الكتابة والإضـافة، وبدأت

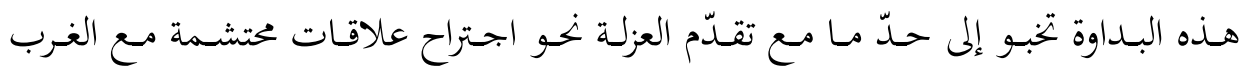

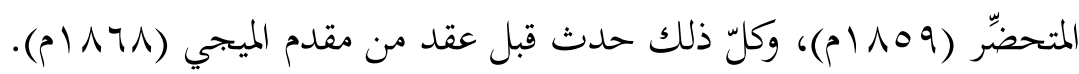

\section{ثانياً: دينامية التنوير في عهد الميجي (التنمية المتحضِّرة)}

قـد يجـادل أحسـهم مُّن في عقله اعـتراض على وجـود حضـارة يابانيـة، إلّا أنّ الثقافة اليابانية ذات عراقة تاريخية وأناقة حضارية، ترجع إلى ما قبل عصر (نارا) عصر المؤسسات، وهي ثقاقة اقتدرت على استيعاب نصوص الحضارات الكبرى، والإفادة منها أكثر ميّا أفاد الصينيون من نصوصهم مباشرةً، ولا سيّما أنّه قد "درج الناس داخل ما يعرف اليوم بالصين على استخدام عبارة الحضارة منذ ما لا يقل عن ألفي سنة." اء وقد حُقَّ للثقافة اليابانية أن

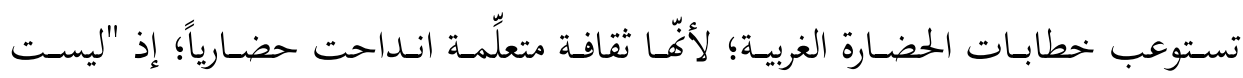
الثقافة سوى تعلّم الحضـارة." ب؛ ووظيفة هذه الثقافة أَّها "تخلق علاقات بينـا وبين النظام

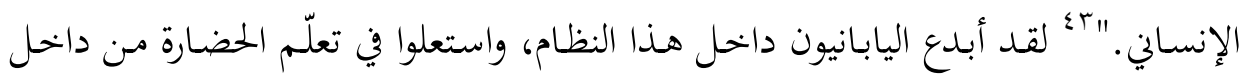
التراث الصيني، ورسخوا في العلم والمعرفة، فبات الفعل الحضاري فعلاً لصيقاً بهم. وقد شكَّلت العزلة ثقافة اليابـان المتناغمـة، ثمّ قطفت اليابان -مـا بعد العزلة- نتائج الحضـارة عنــدما ترجمـت الثقافـة الحضـارية إلى علـم؛ إذ "لـيس العلـم سـوى بعـض نتـائج •؛ كحلارك، جي جي. التنوير الآتي من الشـرق، ترجمة: شوقي جـلال، الكويت: البحلس الوطني للثقافة والفنون

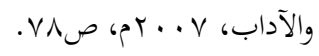

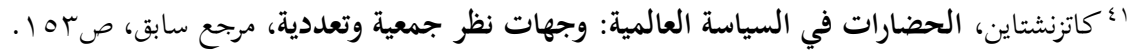

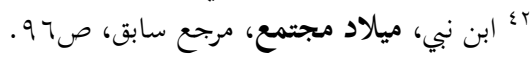

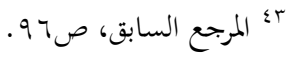




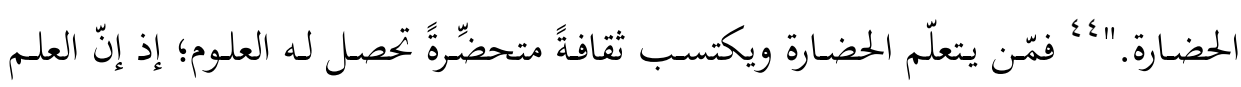

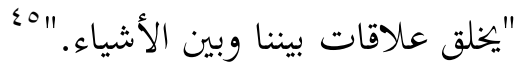

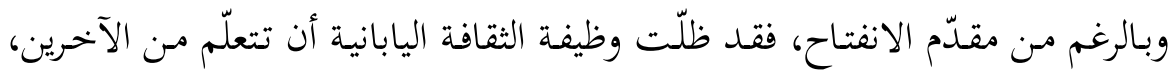

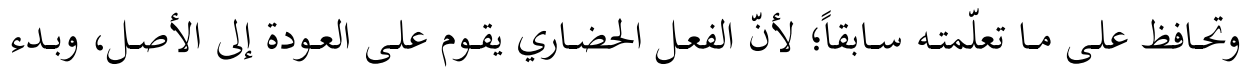
الجديد بتعبير كونفوشيوس، أو العودة إلى الأصل بطريق الأمام.

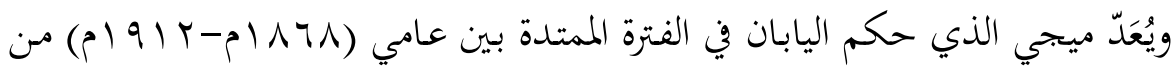

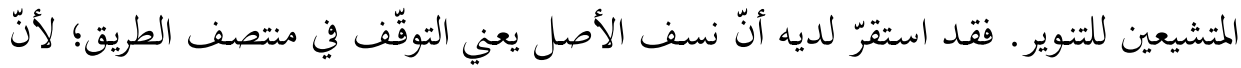

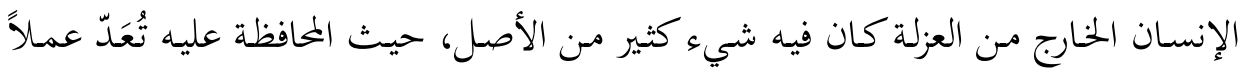

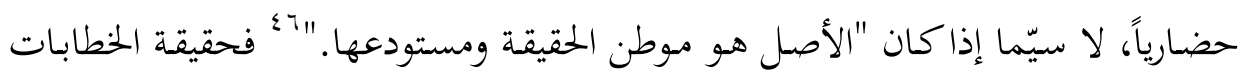
الحضارية لا تتكشّفها إلّا ثقافات الأصول. لإن.

إنّ قطيعة ميجي مع توكوغاوا كانت قطيعةً مع الفترة، لا مع الثمرة. وإذاكان لكلّ فترة

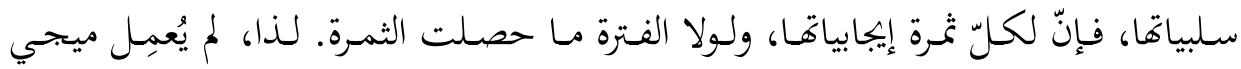

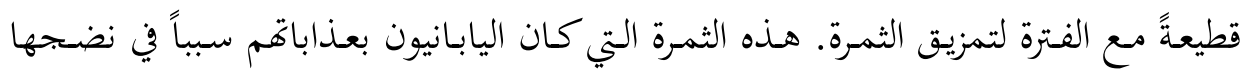
وإيصالها إلى أجيال تعيش مُدَداً أخرى تستحضر فيهر فئا الخصوصيات المشتركة.

فلو أنّ اليابـان تخلّت عن الخصوصيات، وأعملت قطيعةً مع الأصل، بحجـة أنّه مـن

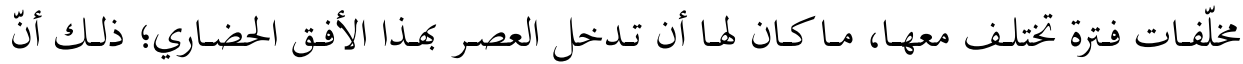
الثقافة بوصفها مستودعاً للأصول تأخحذ دور المنقذ الحضاري كلّما حدثاث تغيير في الأفق، حيث تعكس الثقافة بُعْدها الحضاري على مَن تفيد منهم، فتحصل لها الإفادة العلمية من

$$
\text { غير أن تنزف كثيراً من قيمها. }
$$

إنّ أهم ما ابتذرته العزلة وأثمرته ليس إبحازاتا الكبرى وحسب، بل بروز معالم في طريق الثقافة المتحضِّة. وأهـم مـا استحصده الإقطاع واستخلصه ليس فائض الأرض، وإنّما إيجاد

$$
\begin{aligned}
& \text { ؛؛ المرجع السابق، ص79 } 97 .
\end{aligned}
$$

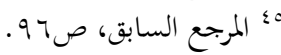

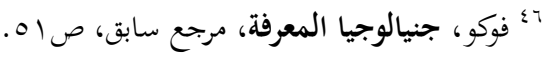


تكتلات بحاريـة جديـدة. فلـيس بـدعاً مـن القـول إنّ هـذه الإرهاصـات كانـت منطلقـات

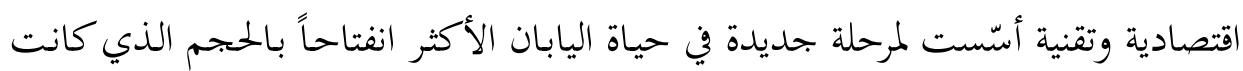
فيه أكثر عزلةً.

إنّ القاسـم المشـترك بـين العزلـة والانفتـاح هـو العناصـر الحضـارية (الإنسـان، والأرض، والوقت)، إلّا أنّ الفارق بينهما هو اتصاف هذه العناصر بشيء من البداوة في فترة العزلة،

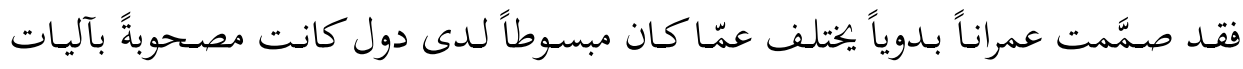

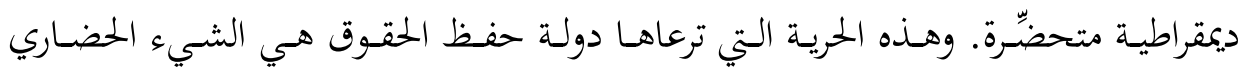

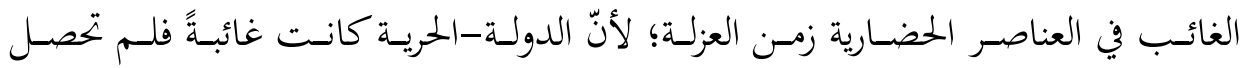

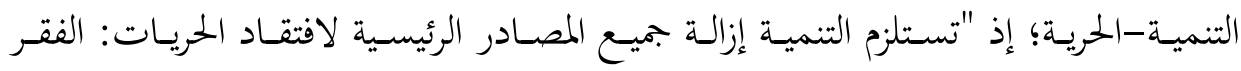

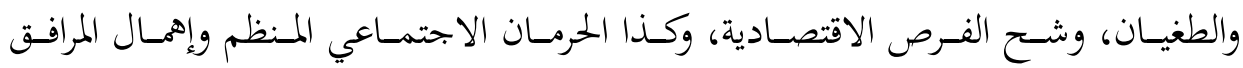

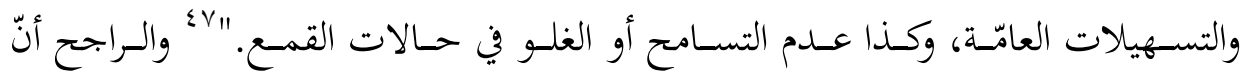

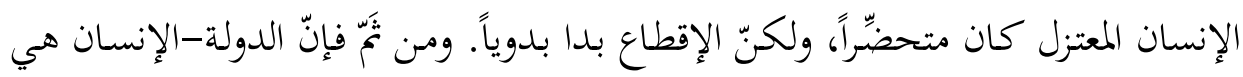
الحلقة المفقودة في المعادلة الحضارية التي بجست تنميةً لمُ تكن متحضِّرةً؛ وإلا، لماذا القابلية

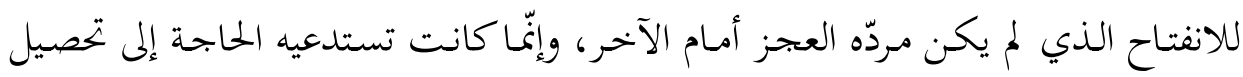

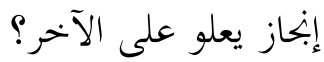

لقد وقف التنوير على الإجابة عن سؤال: هل العناصر الحضارية (الإنسان، والأرض،

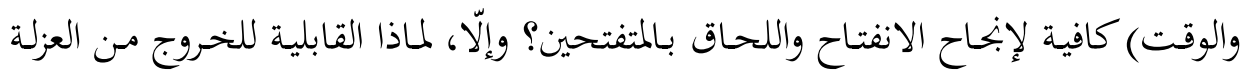
التي هيَّأت إنساناً يحسن أن يعيش من غير عزلة أيضاًُ

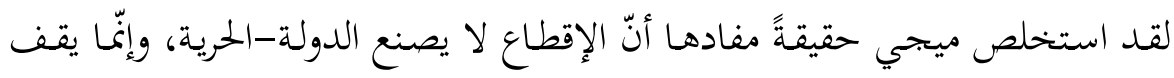

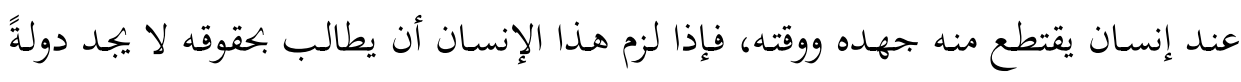
تعينه. فالحقوق مقتطعة؛ لأنّ الدولة-الإنسان بحتزأة، وغير مرئية لدى العامّة. أمّا المرئي فهو القمع الذي قمابه الحقوق.

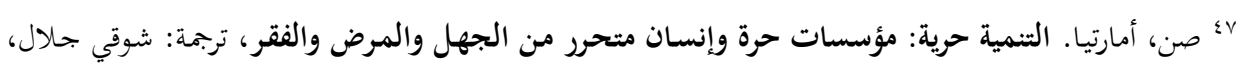

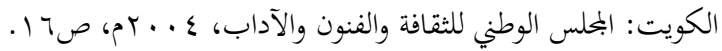


لقد وجب على ميجي، إذن، إعادة الحقوق؛ فكيف تُسترجَع الحقوق والناس ما يزالون

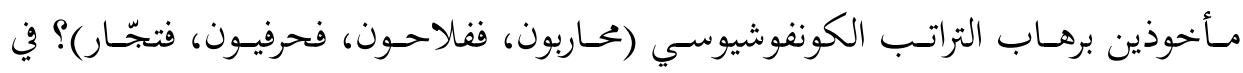

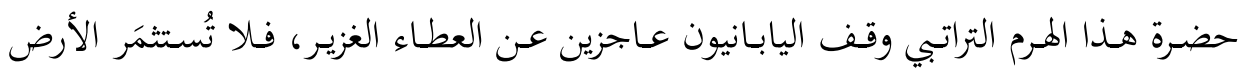

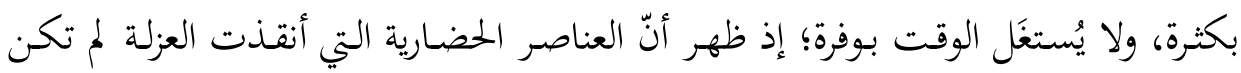

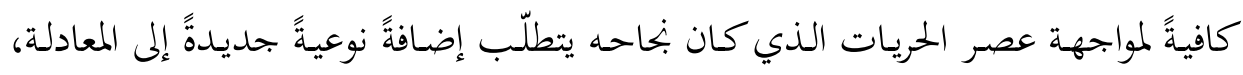
حيث إضافة الدولة بوصفها شريكاً حضارياً يخلع على المعادلة الحضارية المُّختزئلة بُعْداً

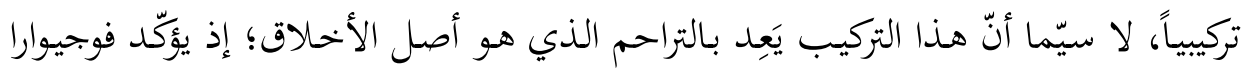

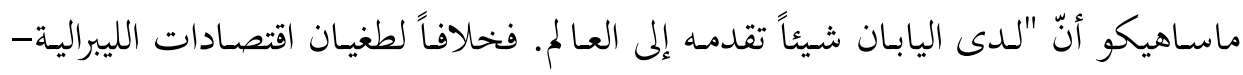

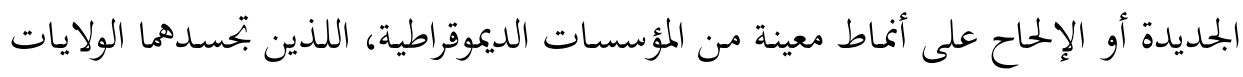

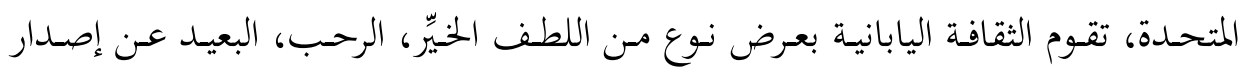

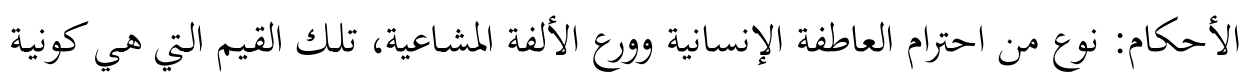

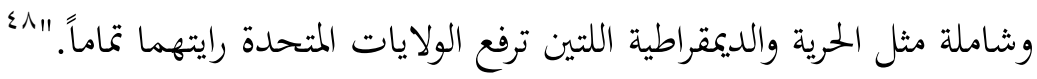

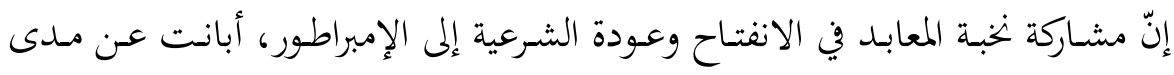

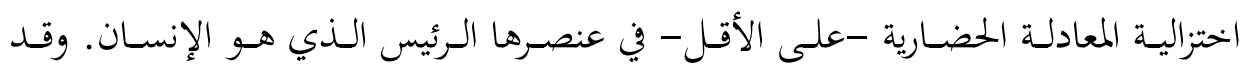

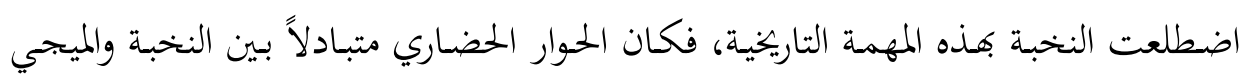

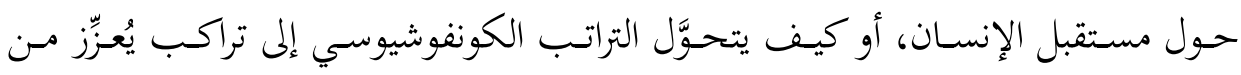

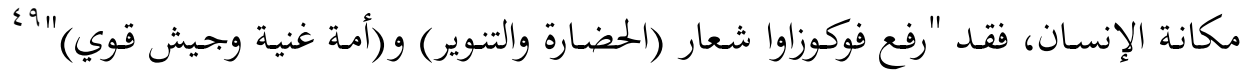

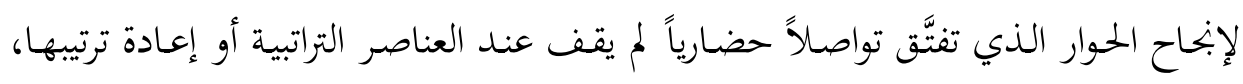

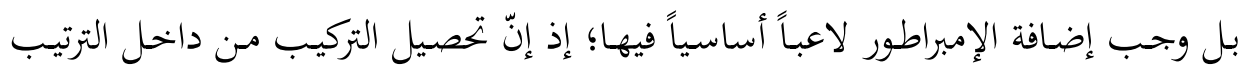

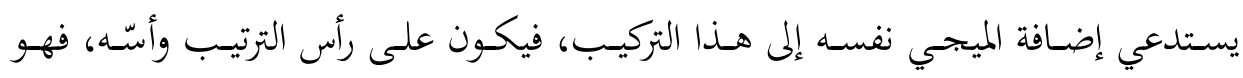

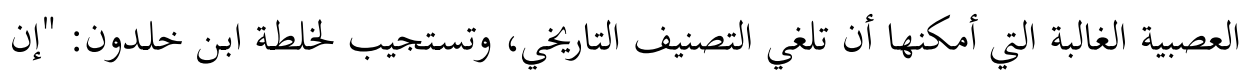

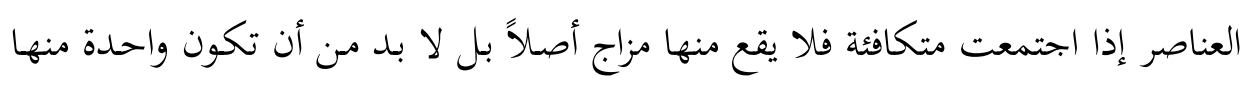
^^ ليهني، ديفيد. مبادرة الساموراي إلى نجدة هنتنغتون: اليابان عاكفة على تأمل أدوارها، ضمن: كاتزنشتاين،

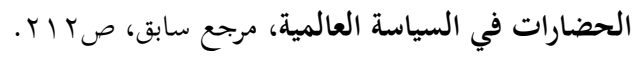

${ }^{49}$ Hopper, Helen M. Fukazawa Yukichi: From Samurai to Capitalist, New York: Pearson Education, Inc, 2005, p 60. 


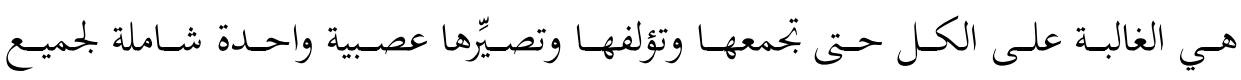

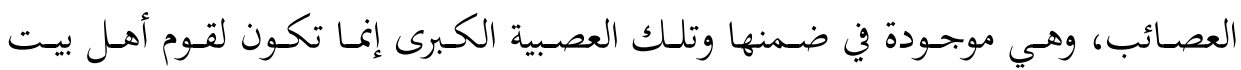
ورئاسة." العصائب وتص

والسلطان هو إنسان يُعترَض أن يكون حاضراً -اسماً وفعلاًَ- في المعادلة الحضارية،

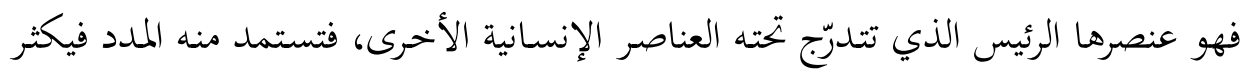

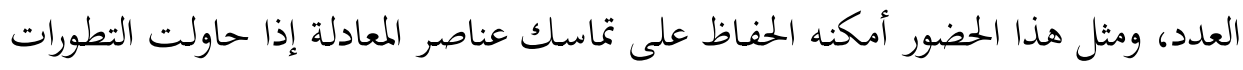

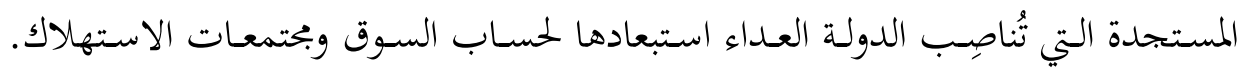

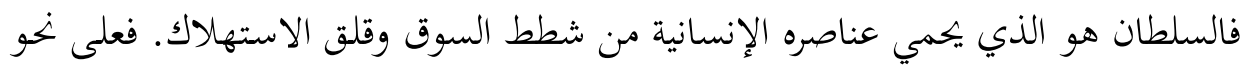

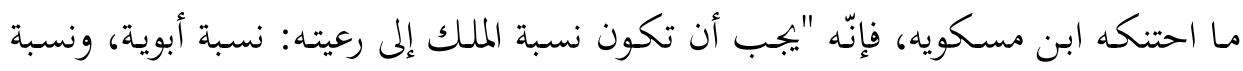

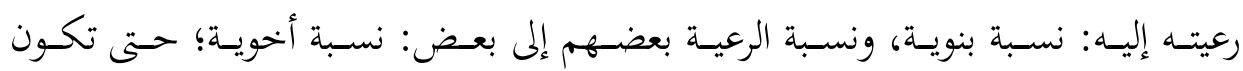

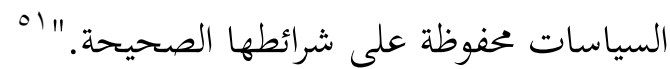

وعلى الرغم من إقرارنا بأنّ شبكة العلاقات الاجتماعية قاربت على الكمال في أواخر

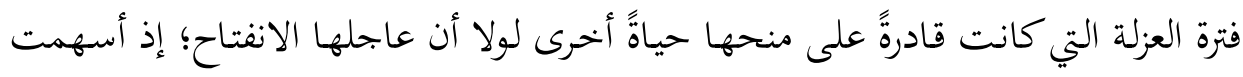

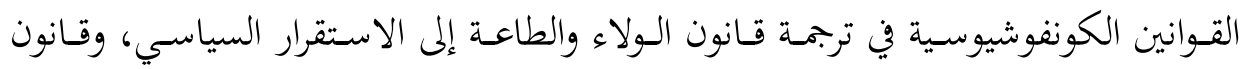

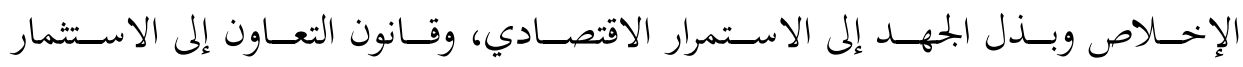

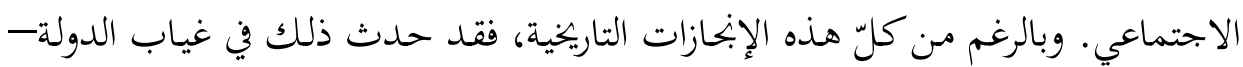

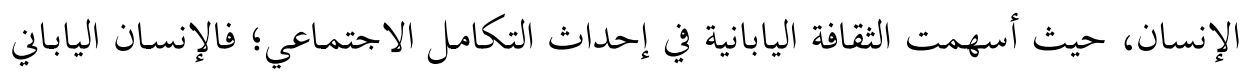

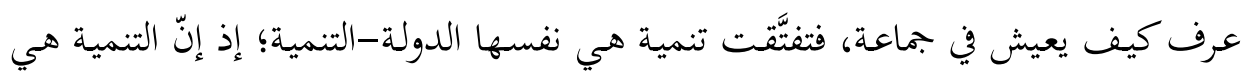

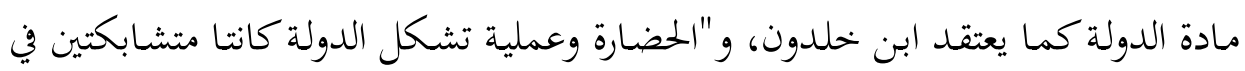

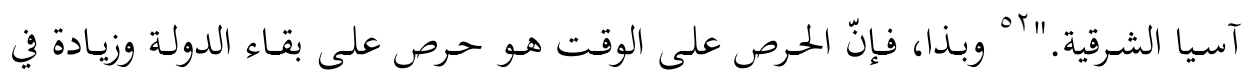

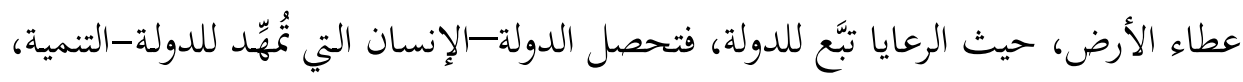
وعلى نخو ما جرى في فترة التنوير التأسيسية.

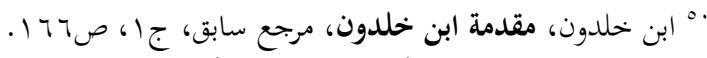
" ابن مسكويه. تهذيب الأخلاق وتطهير الأعراق، تحقيق: ابن الخطيب، القاهرة: المطبعة المصرية ومكتبتها، طا، 


\section{1. تأسيس الدولة-الإنسان:}

لقد تأسّست الدولة-الإنسان وَفق مراحل مدروسة، أبرزها:

أ. استعادة شرعية الإمبراطور واعتباره إنساناً فاعلاً ومُنورًاً، مع الاحتفاظ برمزيته الإلهية

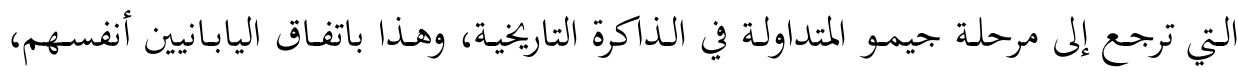

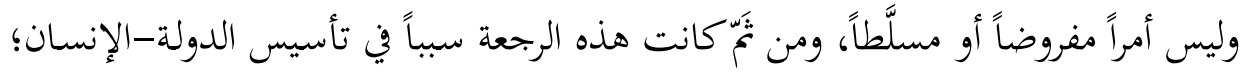

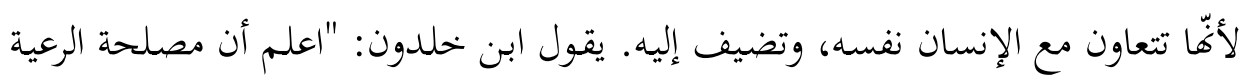

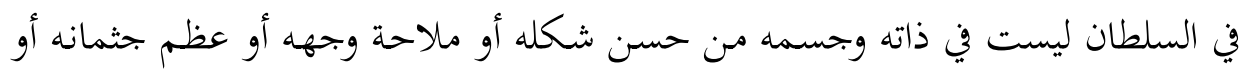

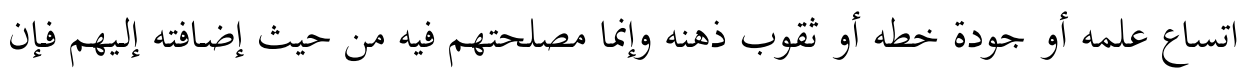

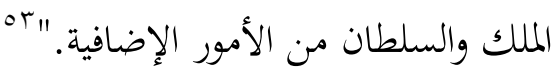

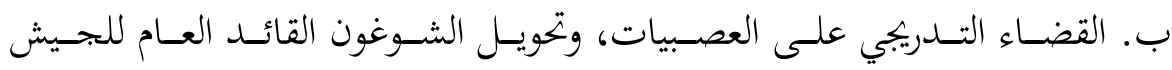

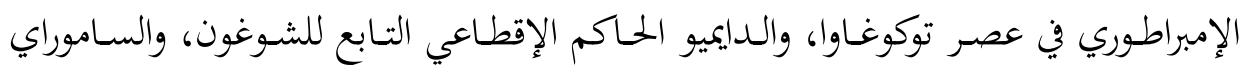

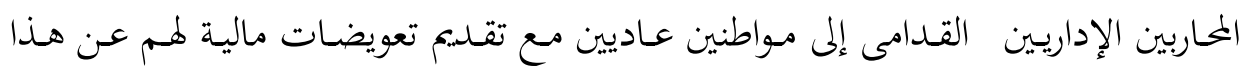
التنازل التاريخي. لقد جرَّد ميجي الساموراي من سيوفهم الممتشقة، وأسَّس جيشاً عصرياً.

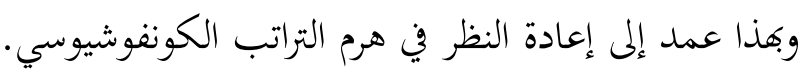

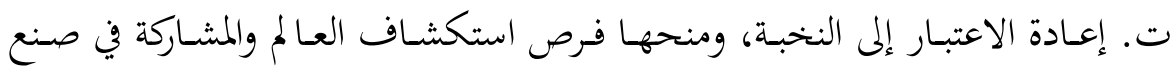

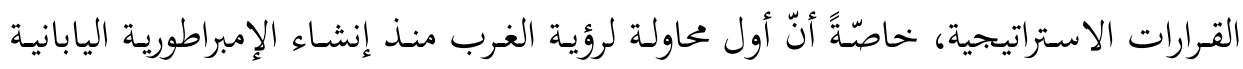

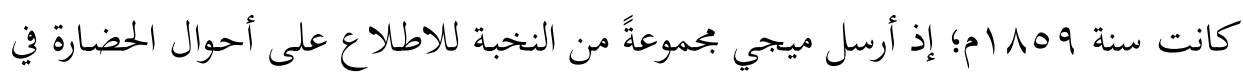
أوروبا وأمريكا.

ث. تحسين أوضاع الفلاحين، وإعـادة حقوقهم بتعويضات مالية، ودمج أبنائهم في

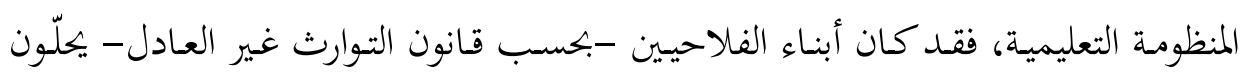

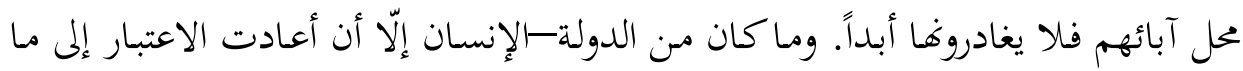


نسبته • 9\% من السكان الفلاحين؛ إذ "تعمل الدولة-الأمة في جوهرها على تزويد أفرادها

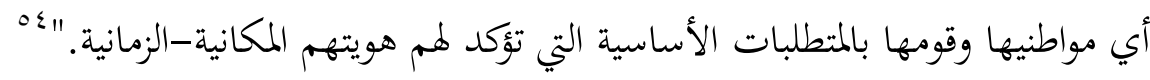

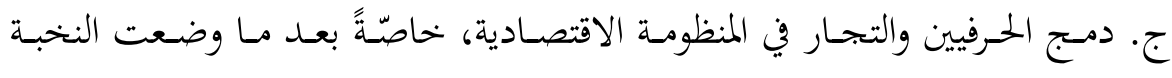

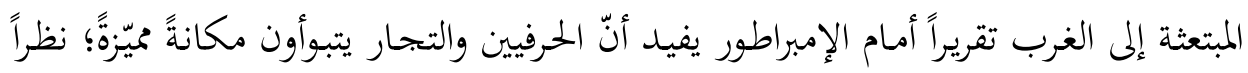
إلى ما يقدّمونه للتنمية، فأساس الاقتصاد هو المال في القاموس الإنمائي الغربي.

\section{r. تأسيس الدولة-التنمية:}

أفرزت الدولةُ-الإنسانُ الدولةَ-التنميةً، وهذه أبرز إبحازاتها:

أ. هزيمة اليابان للصين؛ فالانتصار على الآخر تنمية. يقول فوكوزاوا: "إني أرى البلاد

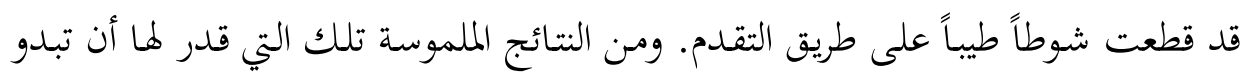

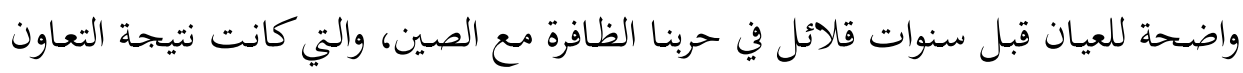

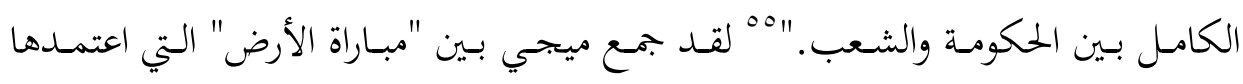

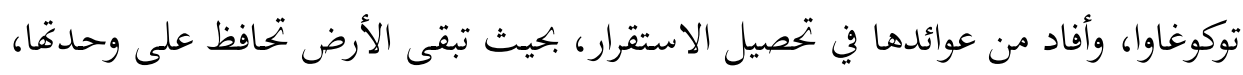

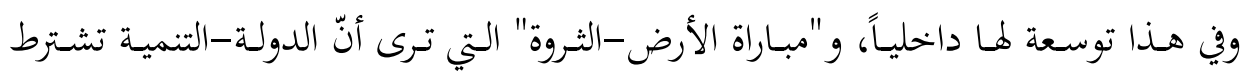

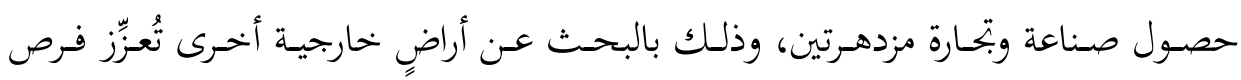

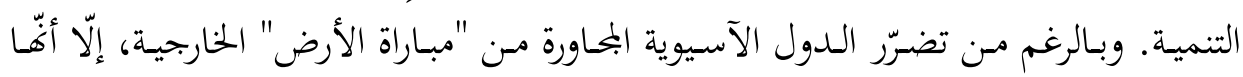

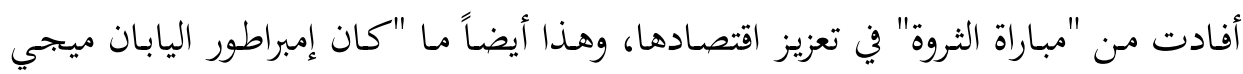

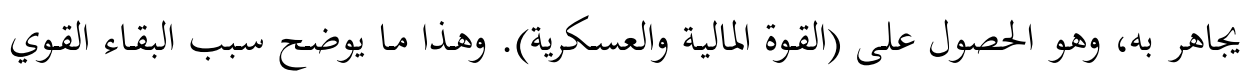

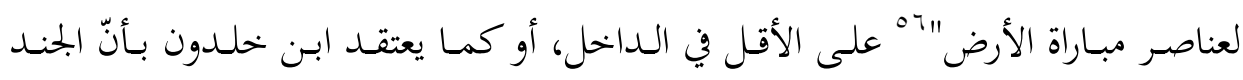

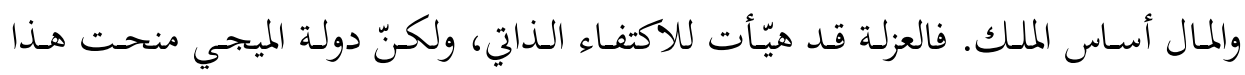

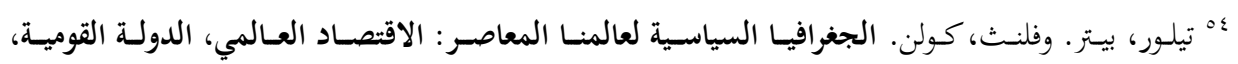

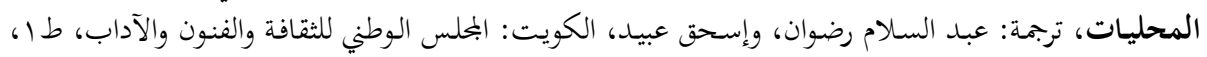

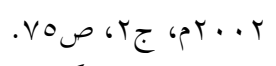

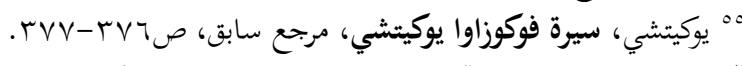

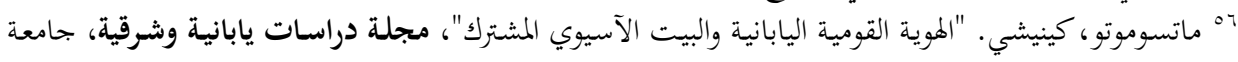




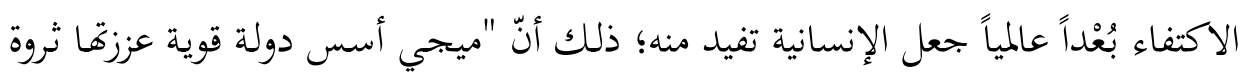

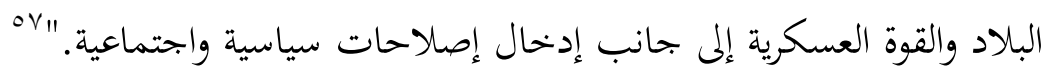

ب. إسهام الساموراي في تطوير التعليم؛ نظراً إلى امتلاكهم الخبرة الإدارية والصرامة

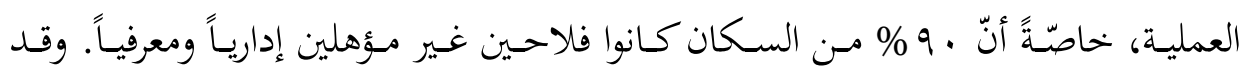

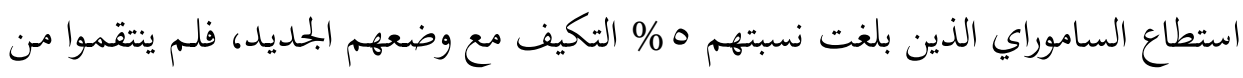

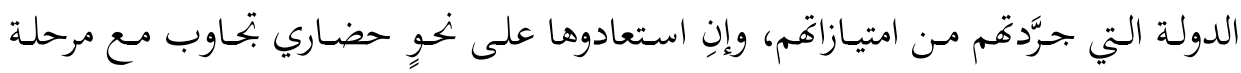

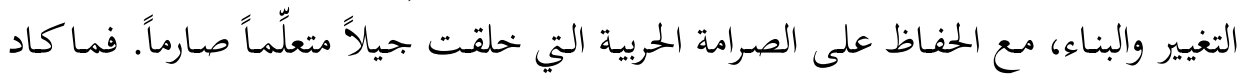

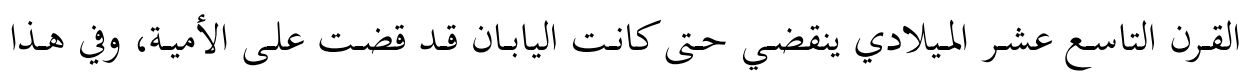

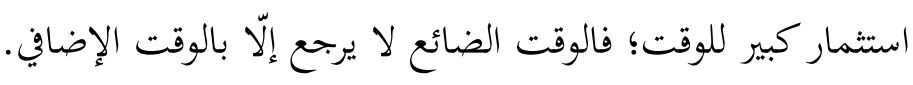

ت. إفادة النخبة من الدولة-الإنسان، ثُّ إفادة الدولة-التنمية منها؛ فقد كان إن وفاء

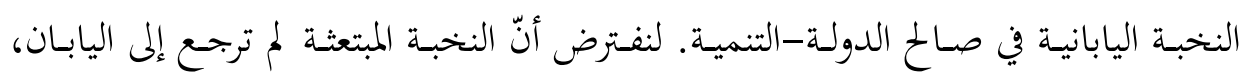

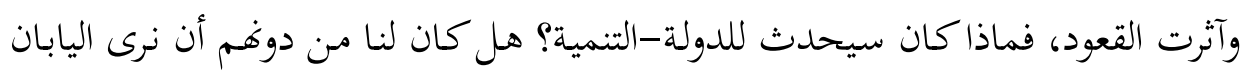

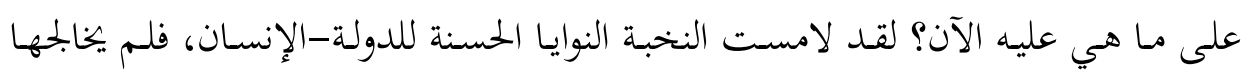

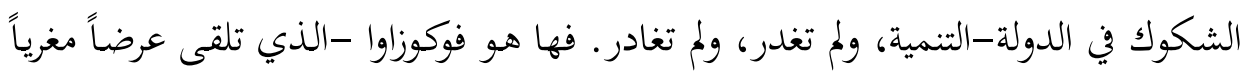

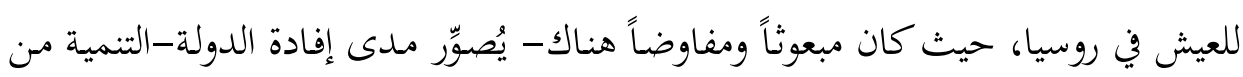

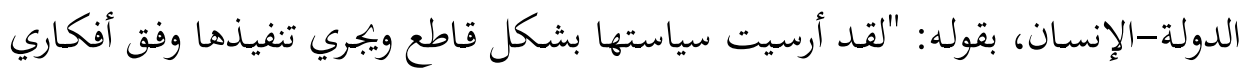

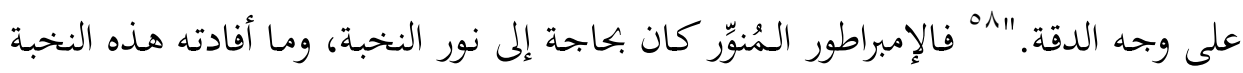

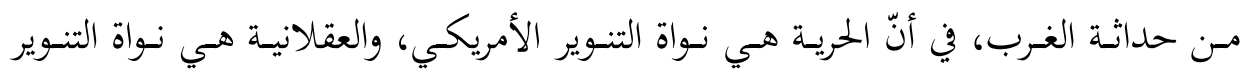

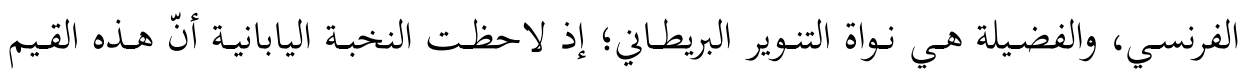

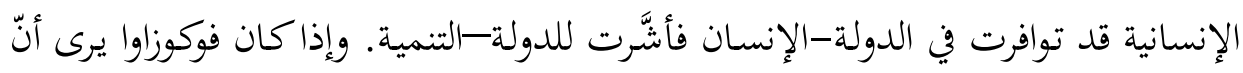

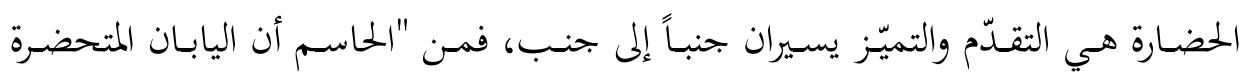

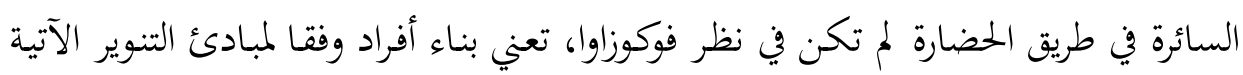

${ }^{57}$ Hayashi, Takeshi. The Japanese Experience in Technology: From Transfer to SelfReliance, Tokyo: United Nation University Press, 1990, p40. 
مـ الغرب فقط، بـل وبناء (مواطن قومي-وطني) أمـة ذات إرادة جماعية قادرة على دعم دولة الميجي.

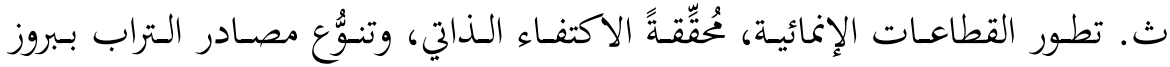

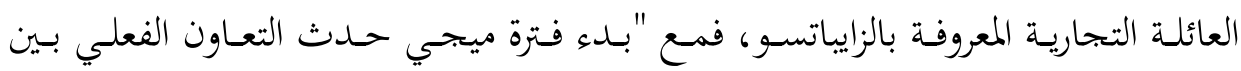
التجمعـات الزراعيـة والجمعيـات الصـناعية، فقبـل هـذه الفـترة كانـت الجمعيـات الصــاعية تقتصر في نشاطها على تقديم المشورة في الجوانب التقنية للإنتاج الزراعي؛ أما في فترة ميجي

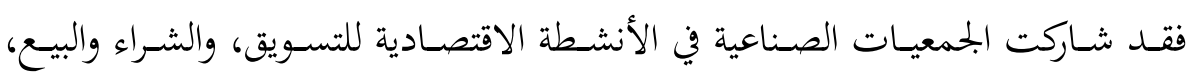

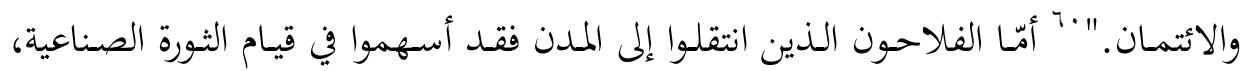
وتنويع الأسواق.

وعمومـاً، فـإنّ "حريـة دخهـول السـوق يمكـن أن تكـون هـي ذاتهـا مســاهمة مهمــة

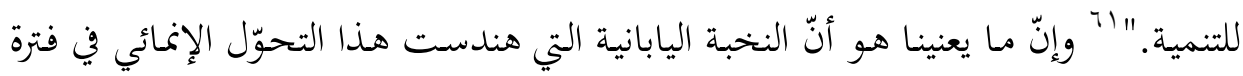

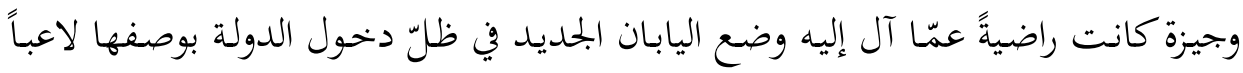

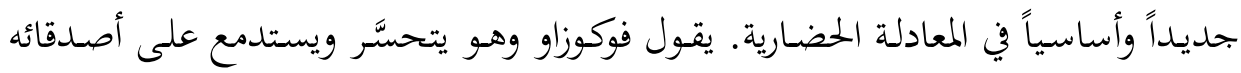

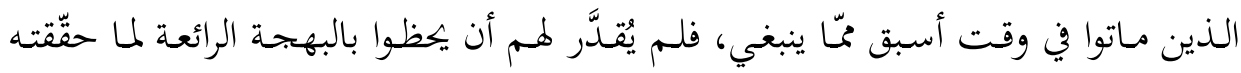
الدولة-التنمية: "الحاضر، في فاية المطاف، هو نتيجة الماضي. وهذه الحالة البميدة لبلادنا لا يمكن إلا أن تكون ثمرة الميراث الطيب الذي ورثناه عن أسلافنا، فنحن المخظوظون الذين

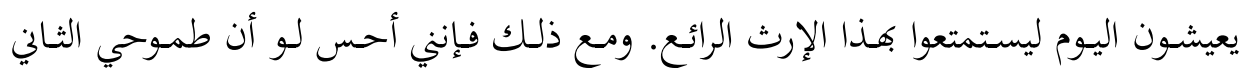

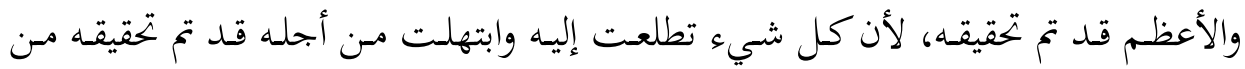

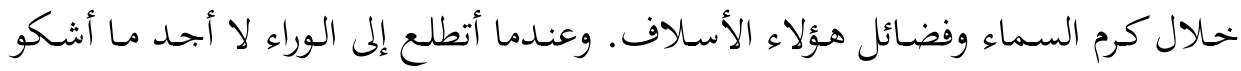

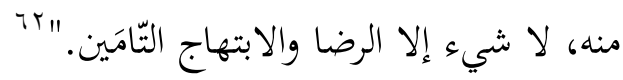

9 كاتزنشتاين، الحضارات في السياسة العالمية: وجهات نظر جمعية وتعددية، مرجع سابق، صلو 1 . ${ }^{60}$ Okazaki, Tetsuji and Okuno-Fujiwara, Masahiro (eds.). The Japanese Economic System and its Historical Origin, Oxford: Oxford University press, 1999, p245.

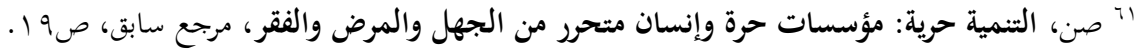

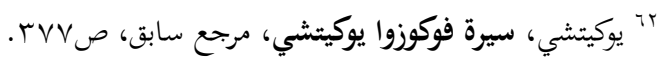


خحلاصـة القـول إنّ العناصـر الحضـارية المركّبـة والمسـتدامة (الدولـة، الإنسـان، الأرض، الوقت)، تتقصَّد تحصيل تنمية مركبة؛ لأنّ الدولة دولتان. "إن السلطة في الدولة سلطتان: سلطة الدولة، وهي سلطة طبيعية أصلية، وسلطة الحاكم، وهي سلطة تفويضية مستمدة

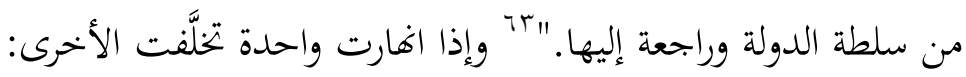

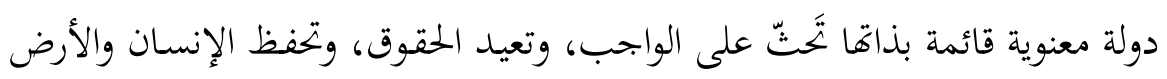

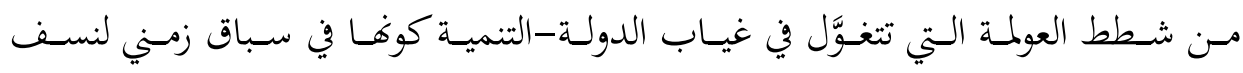
الخصوصيات.

ودولـة ماديـة هي نفسـها الإنسـان والأرض والوقــ؛ "إذ تبقى الدولـة أسـاس التعاقــ

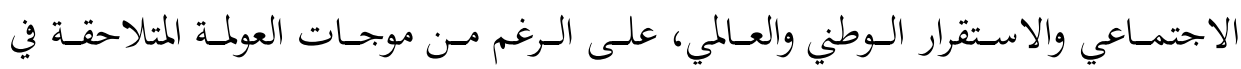

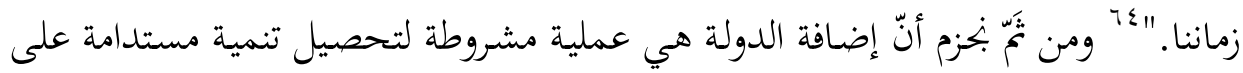

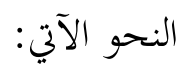

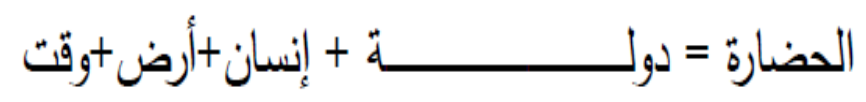
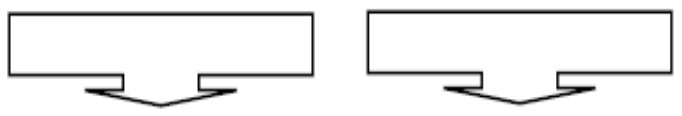

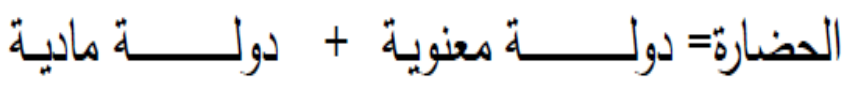

وبـذا، فِإنّ التنميـة المتحضِّرة تحصـل بحصـول الدولـة-الإنسـان الرشـيدة التي تتصـدَّر العناصر الأخرى المفيدة.

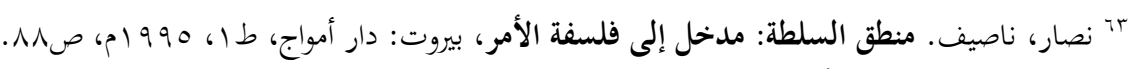

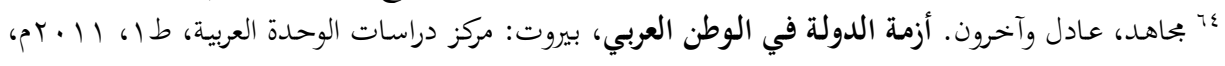


ثالثاً: مسالك الإفادة من عناصر معادلة الحضارة اليابانية

\section{1. مقدمة واستهلال:}

إنّ مسالك استخلاص الدروس المستفادة من النماذج الإنمائية الناجحة، تأتي غالباً

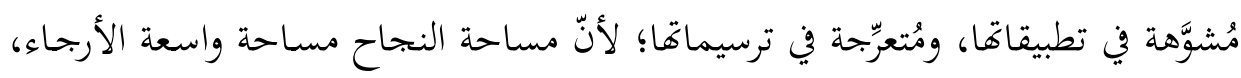

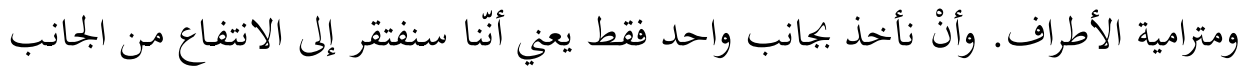

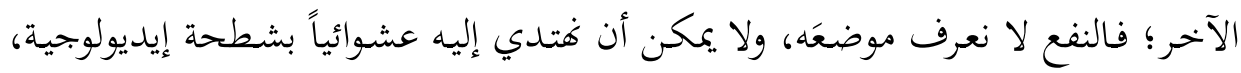

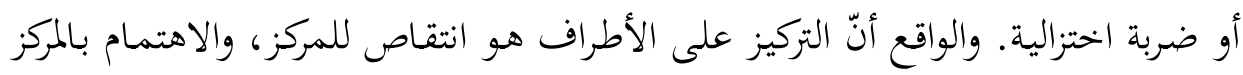
هو إهمال للأطراف.

توجد نماذج إنمائية ناجحة وصلتنا بما استخلصه أسلافنا من دروسها وعِبرها، إلّا أفّّا

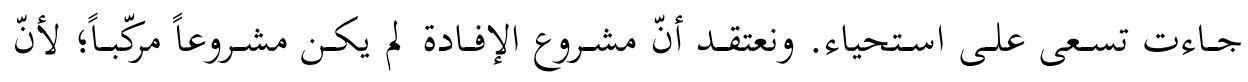

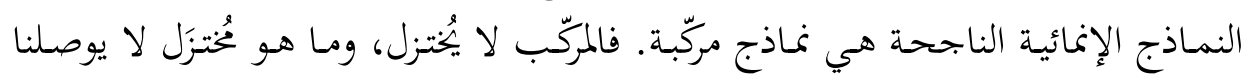

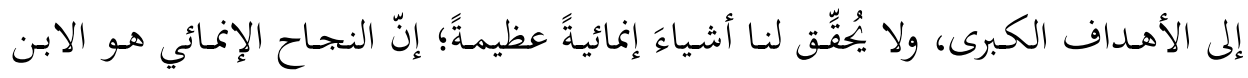

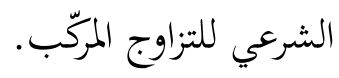

فهل كان هناك مشروع للاستفادة مـ النموذج الإنمائي الذي استخلص أسلافنا

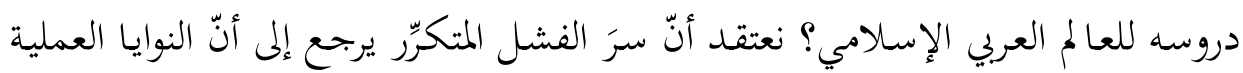

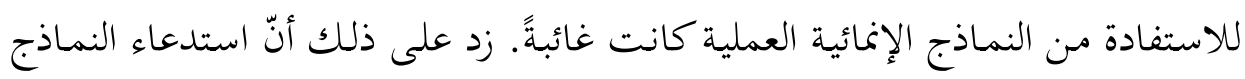

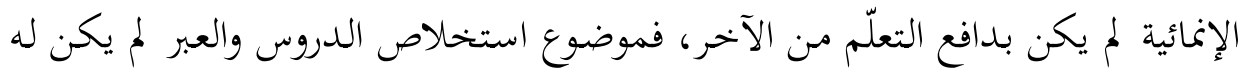

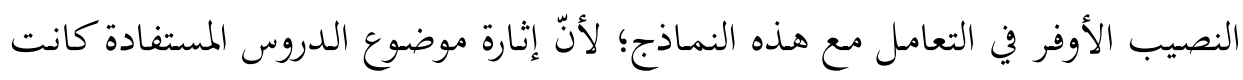

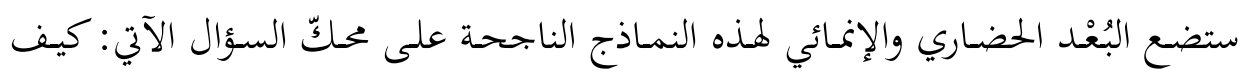

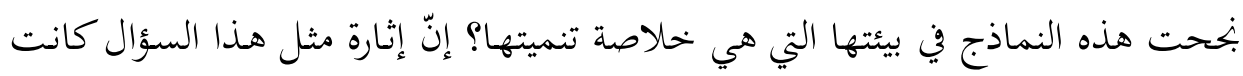

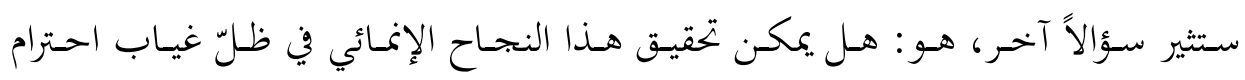
الإنسان؟

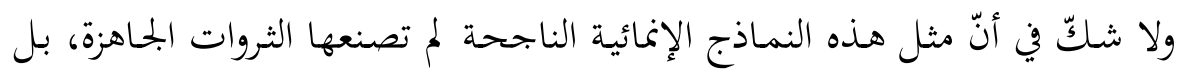

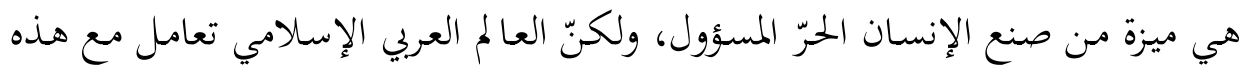


النمـاذج مـن منظـور اقتصـادي مـادي جـاهز، يتـأفَّف مـن الاسـتفادة الحضـارية المكلِّفـة

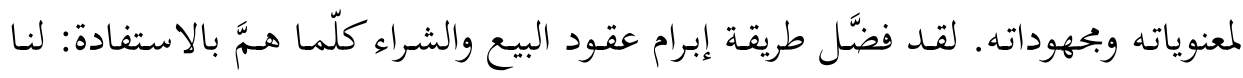

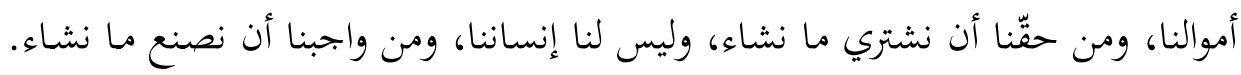

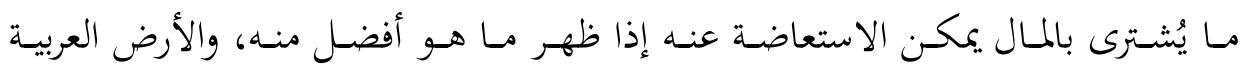

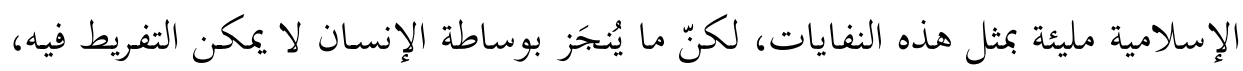

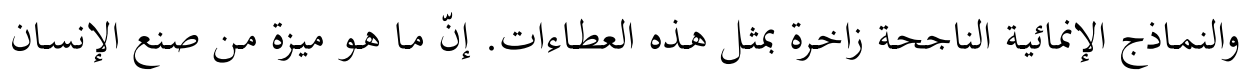

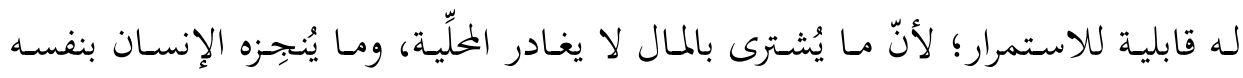

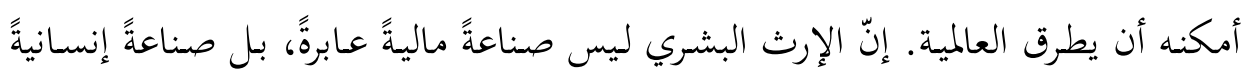
دائبةً.

وإنّ استحضار البُعْد الإنمائي والحضاري في عملية الاستفادة، يغنينا عن اقتناء كلّ

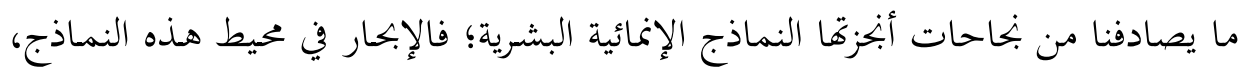

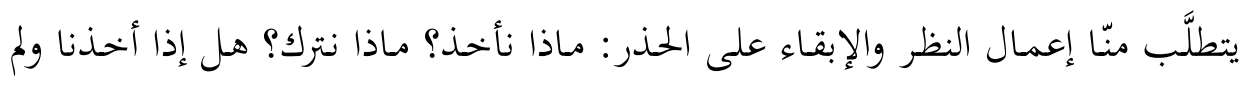
نترك أحسنّا التركيب؟ إذا اكتفينا بما ينفع، فما الشيء الذي ينفعنا؟ كيف نعرف أنّ هذا إذا

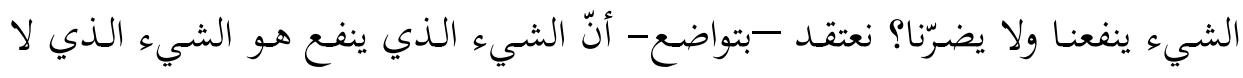

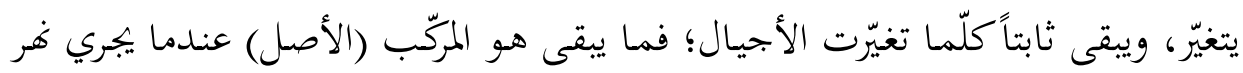

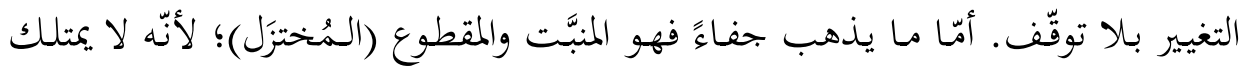
الصفة الإنسانية والطبيعية والوجودية المقاومة. فهذه الصفات الثلاث هي التي لا يتغيّر جوهرها أبداً، وتبقى شاهدةً على الأجيال الغائبة.

وما يهمّنا في هذه الصفات الثلاث الثابتة والمركّبة، هو الإنسان، والطبيعة، والوجود.

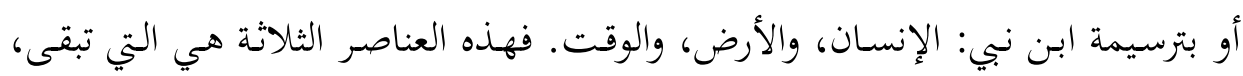
وتتجدّد باستمرار.

ولا شـكَّ في أنّ ابن نبي قد وفَّر علينـا جهـداً عظيماً، وهـو يحيلنـا إلى هـذه العناصر

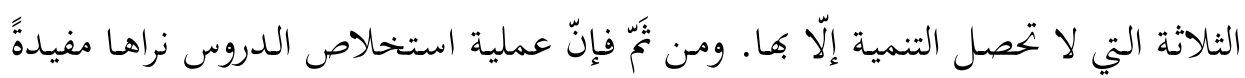

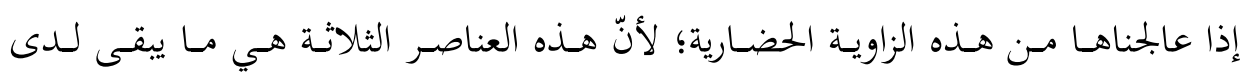




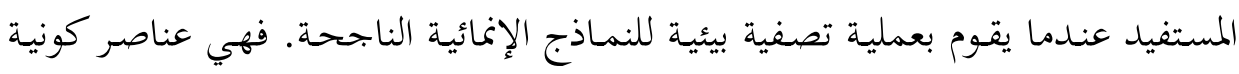
مشتركة؛ ذلك أنّ المستفيد له إنسانه وأرضه ووقته، مثله مثل المستفاد منه.

ونحن إذ نقف على معادلة ابن نبي الحضارية بوصفها عناصرَ معدودةً ومصفوفةً،

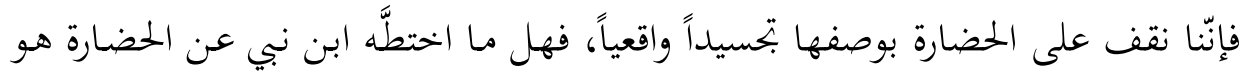

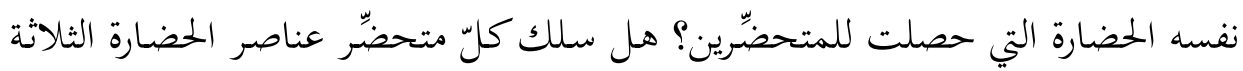

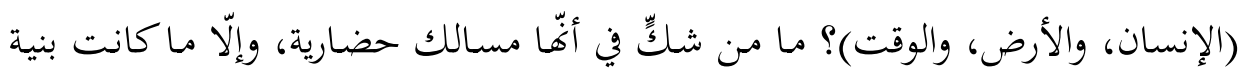

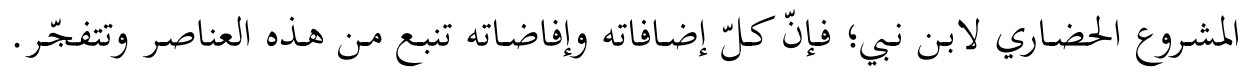

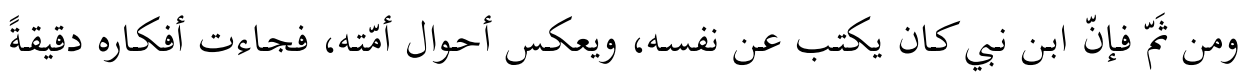

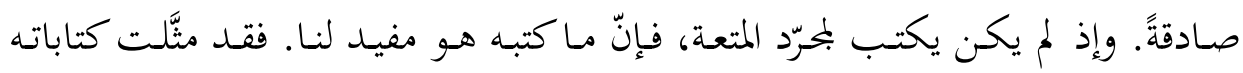

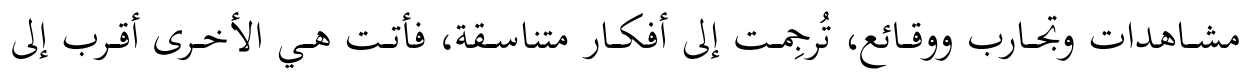

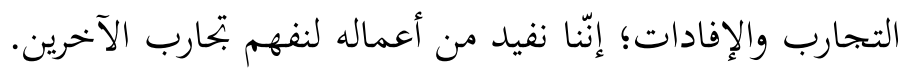
إنّ عناصر معادلة الحضارة عند ابن نبي هي تخربة تحيا داخل فكرة؛ إذّا تحربة تحتاج

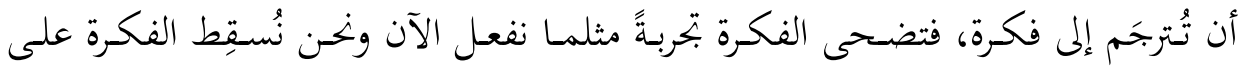

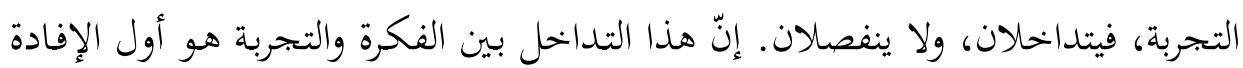

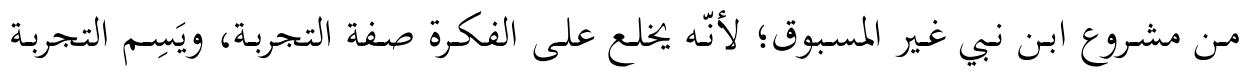

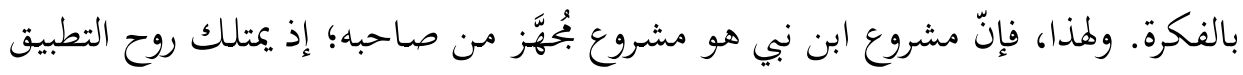

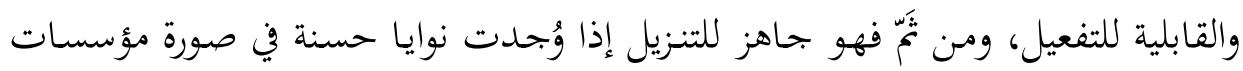

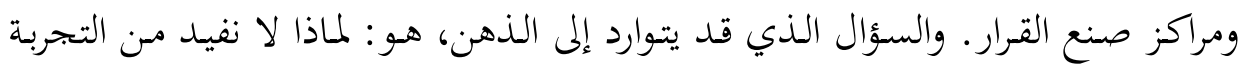

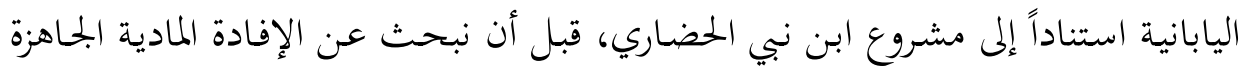

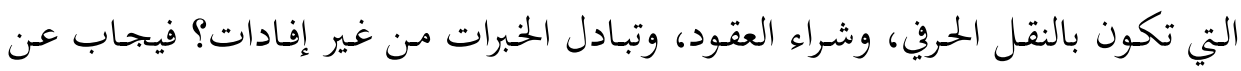

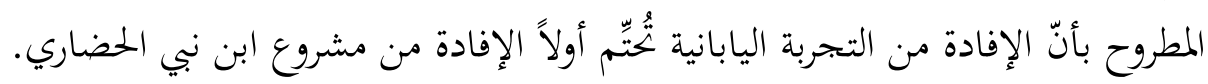
فالإفادة المباشرة من مشروع ابن نبي الحضاري في صورة فكرة، قد يعيننا على فهم

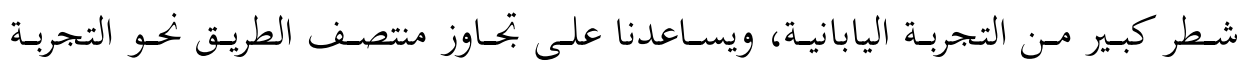

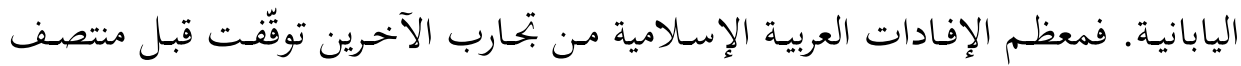




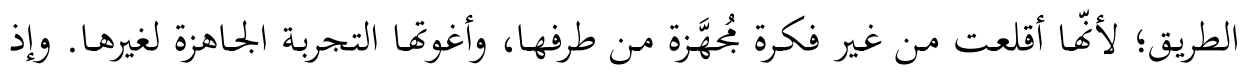

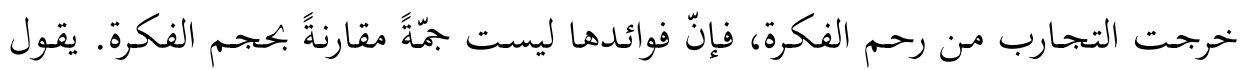

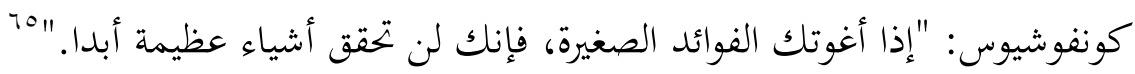
إنّ مـا نستخلصـه مـن ابـن نبي، سـواء في أفكـاره أو بتحاربـه، هـو أنّ البيئة العربيـة

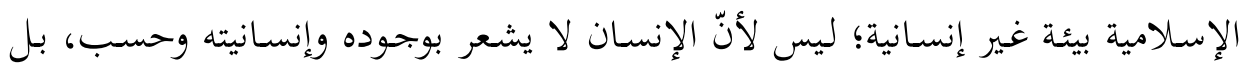

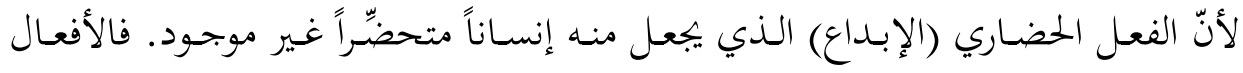
الحضارية هي التي تكون سبباً في حضور الإنسان من عدمده، وهي لا تحصل إلّا باحترام

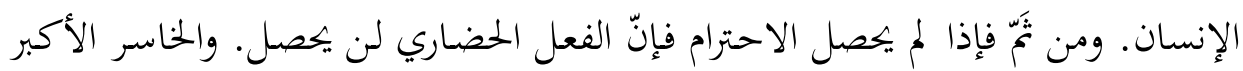
هو الإنسان، ليس في فعله الحضاري وحسب، بل في وجودده؛ إذ الوجود حرية، والتنمية حرية أيضاً.

والعـا لم العـربي الإسـلامي اليـوم هـو مـن غـير إنسـان؛ لأنّ هـذا الإنسـان يفتقــ إلى

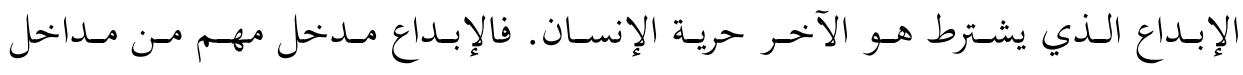
الحضارة، واللاإبداع إغراق في البداوة بصرف النظر عن مدى حضور الإنسان. وهذا هو

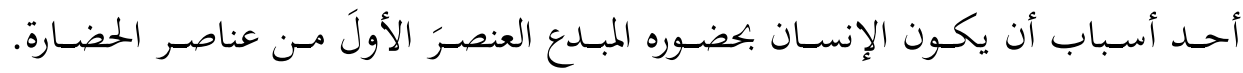

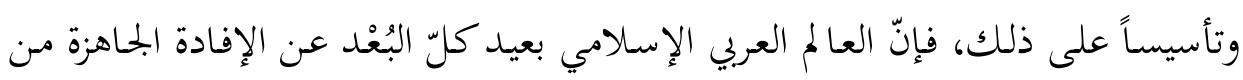

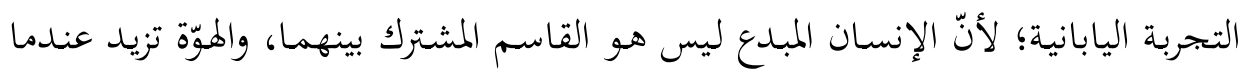
يفتقر هذا الإنسان إلى ضرويات الحرية. في حين كان الإنسان الياباني مبدعاً حتى وهو لئه يقبع في البداوة؛ إذ كان فيه شيء من الحرية، وبات مبدعاً وحرّاً في آلٍ معاً وهو يخرج إلى إلى الحضارة.

يتبيَّن محّا سبق أنّ الحرية هي شرط الحضارة؛ لأنّ الحضارة صناعة دولة يقودها إنسان

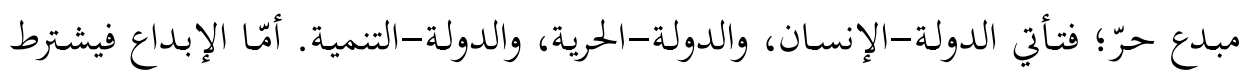

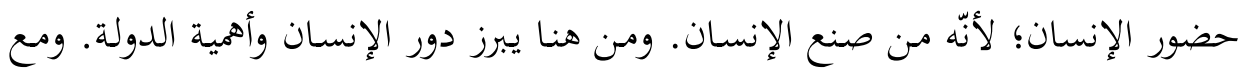


ذلك، فإنّ الإنسان يغرق في البداوة، وإنْ حصل له الإبداع، ولكنّ الدولة تُدخِله الحضارةً

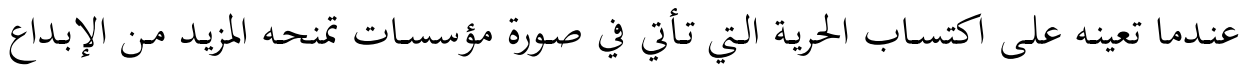

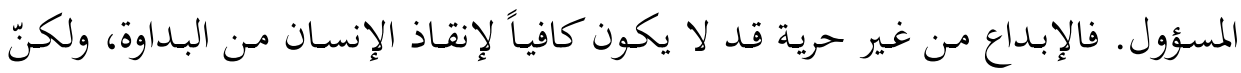

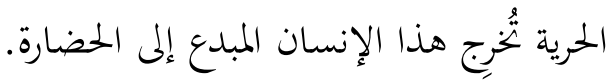

إنّ الدولـة في التجربة اليابانيـة هي رديف للحريـة، خلافاً لمفهوم الدولة السيئ في

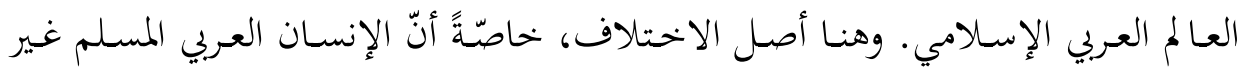

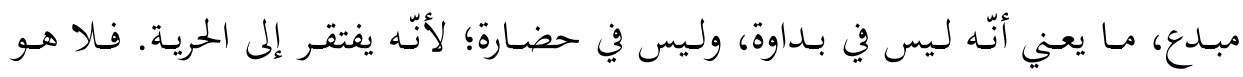

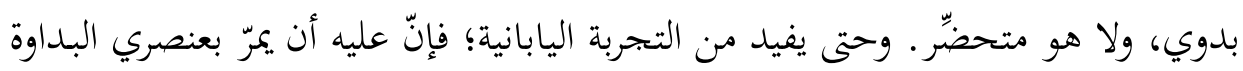

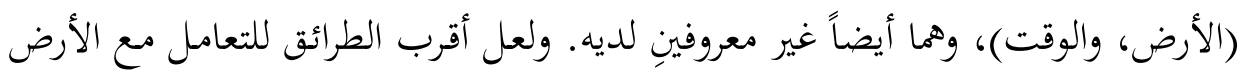

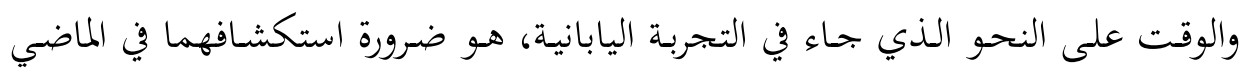

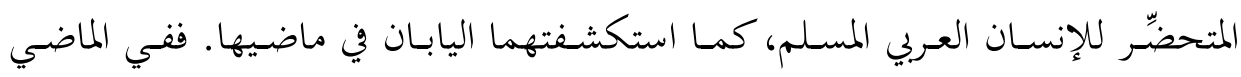

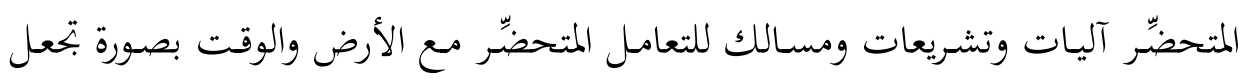

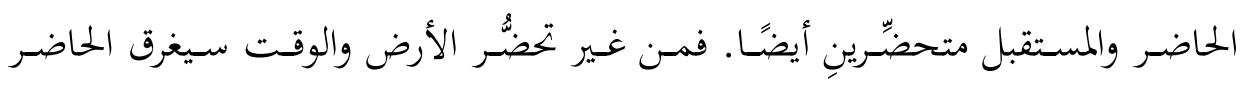

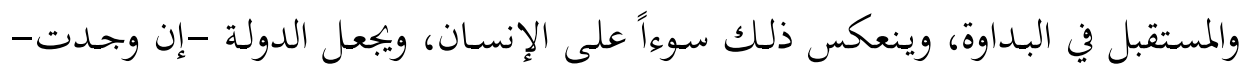

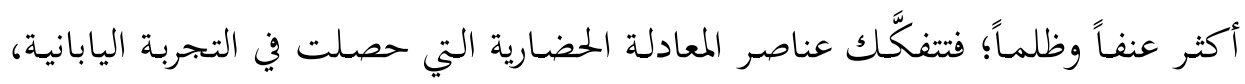
فلا تحصل الإفادة المرّكبة للعالم العربي الإسلامي. عناصي.

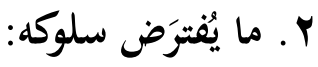

انطلقت التجربة اليابانية من الموروث، وأفادت من الأسلاف، وكذلك مشروع ابن

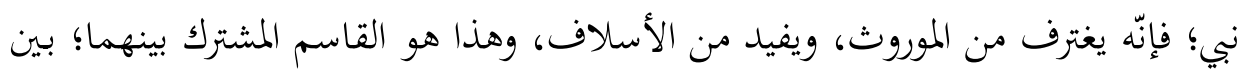

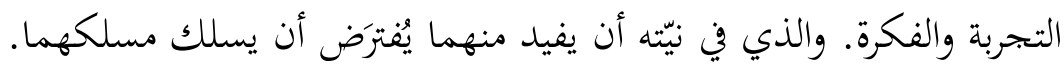
فهل للإنسان العربي المسلم شيء في الماضي المتحضِّر يستطيع أن ينطلق منه كما

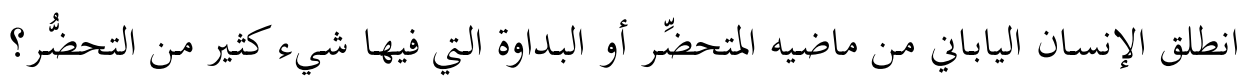

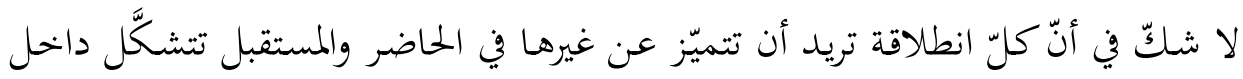


هذا الماضي. فإذا استطاع الماضي المتحضِّر أن يكون انطلاقةً نحو التغيير بالنسبة إلى العالم

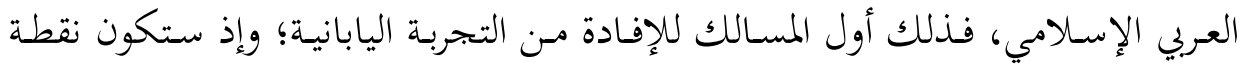

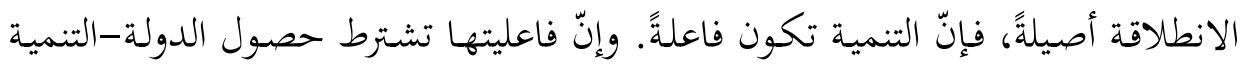

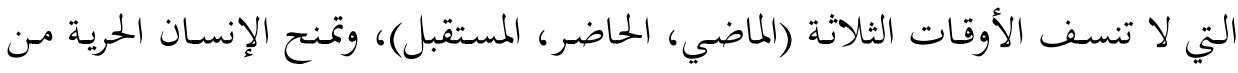

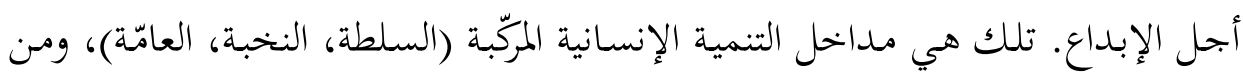

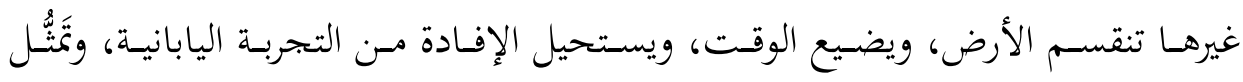

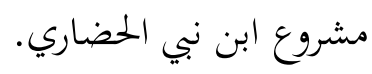

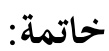

لقد كانت خاتمة العزلة اليابانية مقدّمةً للانفتاح وذات نجاح؛ نظراً إلى أنّ الانفتاح

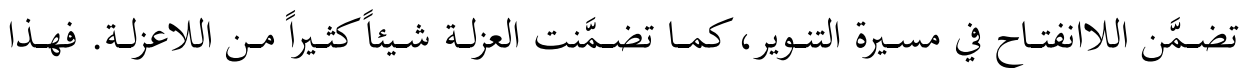

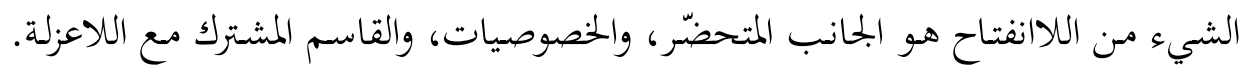

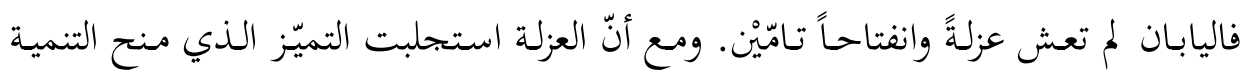

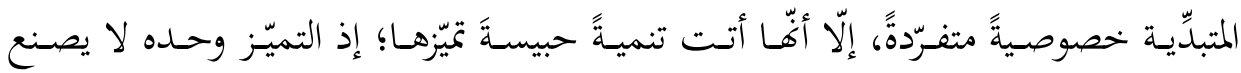

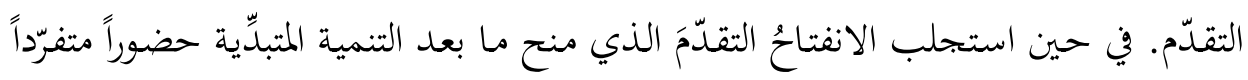
مصحوباً باستمرارٍ يواكب العصر. وقد خلص البحث إلى النتائج الآتية:

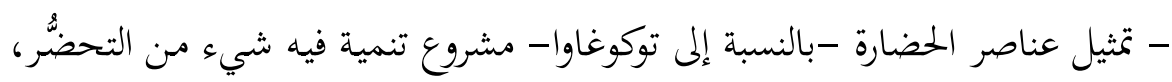

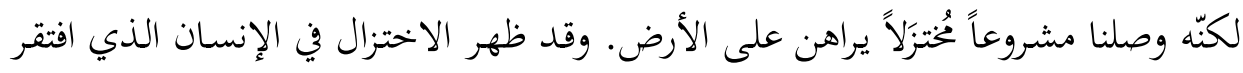

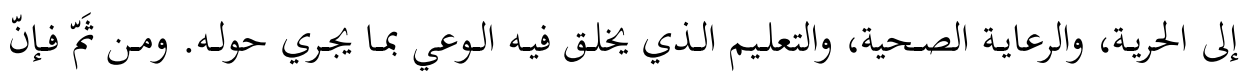

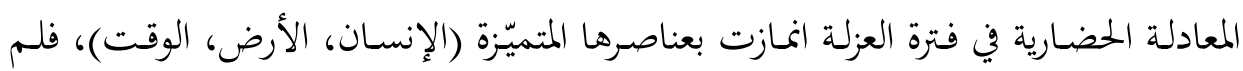

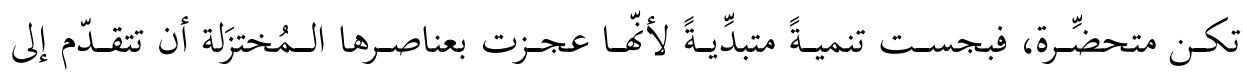

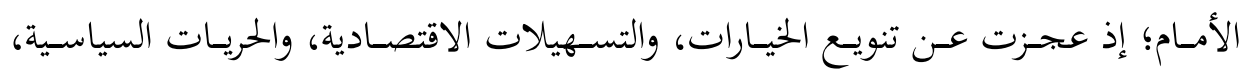
والفرص الاجتماعية. 
- كشف عناصر المعادلة الحضارية الثلاثة الفاعلة عن اللاعزلة ضمن العزلة. فاللاعزلة

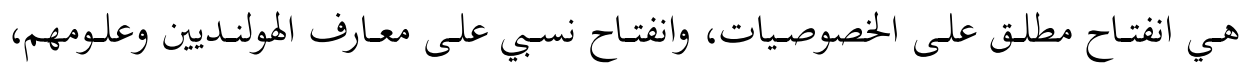

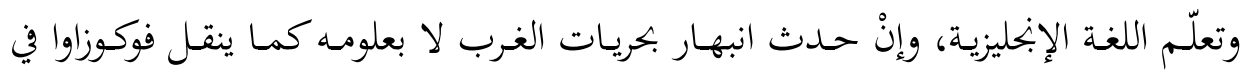

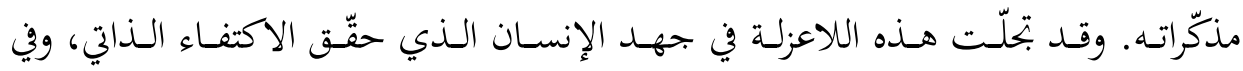
مضاعفة الوقت الذي أملَّ في عمر العزلة.

- عدم كفاية العناصر الثلاثة - كما ارتسمها ابن نبي- لتحصيل تنمية متحضِّرة في

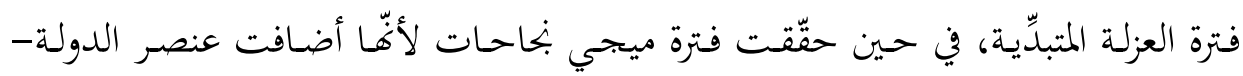

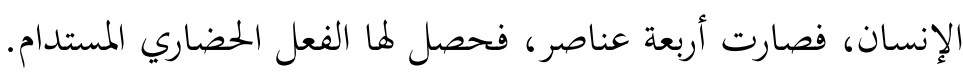
وبناء على ما سبق، فإنبّا نوصي بالآتي: - وقوف العـالم العربي الإسـلامي على التراحم بـين السـلطة والإنسـان، وترجمته إلى عدالة اجتماعية واقتصادية للخروج من المأزق الراهن. - وقوف النخبة العربية الإسلامية على مشكلات الحضارة لدى ابن نبي، ومشكلات الدولة لدى ابن خلدون؛ بغية تشخيص الأوضاع قبل التسرّع في إيجاد الحلول. - إفادة النخبة العربية الإسلامية من النخبة اليابانية في كيفية تعليم الدولة وترشيدها. 